\title{
PRODUÇÃO DE LEITE EM CAPRINOS ALIMENTADOS COM NIVEIS CRESCENTES DE URÉIA
}

\author{
LUIZ EDUARDO DOS SANTOS
}

Orientador: MAX LÁZARO VIEIRA BOSE

\begin{abstract}
Dissertação apresentada à Escola Superior de Agricultura "Luiz de Queiroz", da Universidade de São Paulo, para obtenção do título de Mestre em Agronomia, área de concentração: Nutrição Animal $\theta$ Pastagens.
\end{abstract}

PIR A C I C A B A

Estado de São Paulo - Brasil Junho - 1984 
Aos meus pais, pelo muito que representam em todos os momentos de minha vida of́ereço

A minha esposa Norma e a meus filhos Flávio e André, com todo o carinho, por todos os momentos subtraidos ao seu convívio durante a elaboração desta dissertação

dedico 
o mérito que esta dissertação apresentar é dedicado a meus mestres, desde aqueles que me ensinaram as primeiras letras até aqueles que me guiaram no curso superior, em especial ao meu orientador. A eles devo a minha formação profissional. 


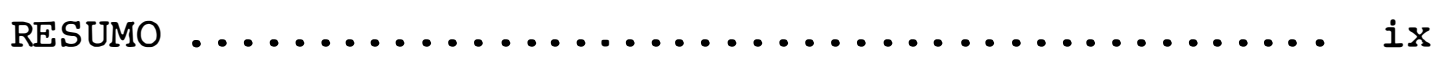

SUMMARY $\ldots \ldots \ldots \ldots \ldots \ldots \ldots \ldots \ldots \ldots \ldots \ldots \ldots \ldots \ldots \ldots \ldots \ldots \ldots$

1. IN TRODUÇÃO $\ldots \ldots \ldots \ldots \ldots \ldots \ldots \ldots \ldots \ldots \ldots \ldots \ldots \ldots$

2. REVisÃo DE LITERATURA $\ldots \ldots \ldots \ldots \ldots \ldots \ldots \ldots \ldots \ldots \ldots$

3. MATERIAL E MÉTODOS $\ldots \ldots \ldots \ldots \ldots \ldots \ldots \ldots \ldots \ldots \ldots \ldots$

4. RESUltados E discussão $\ldots \ldots \ldots \ldots \ldots \ldots \ldots \ldots \ldots \ldots$

4.1. Produção de Leite $. \ldots \ldots \ldots \ldots \ldots \ldots \ldots \ldots \ldots . \ldots \ldots$

4.2. Ingestão de Matéria Seca .............. 28

4.3. Variação Ponderal $\ldots \ldots \ldots \ldots \ldots \ldots \ldots \ldots \ldots \ldots, 42$

4.4. Caracteristicas do Leite .............. 43

5. CONCLUSÕES $\ldots \ldots \ldots \ldots \ldots \ldots \ldots \ldots \ldots \ldots \ldots \ldots \ldots \ldots$

6. LITERATURA CITADA $\ldots \ldots \ldots \ldots \ldots \ldots \ldots \ldots \ldots \ldots \ldots \ldots \ldots$ 
1 Composição química -bromatológica dos in-

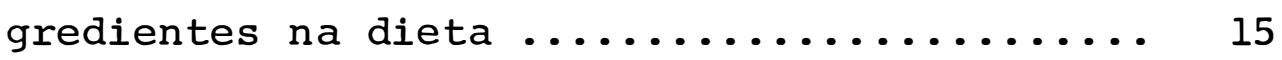

2 Composição ponderal e percentual das rações $\ldots \ldots \ldots \ldots \ldots \ldots \ldots \ldots \ldots \ldots \ldots \ldots \ldots \ldots . \ldots \ldots \ldots$

3 Esquema de adaptação dos animais às dietas ..

4 Distribuição dos animais nos blocos e tra tamentos de acordo com o PV inicial e com a produção de leite no período experimental .. 22

5 Produção total de leite ................ 24

6 Análise da variância dos dados de produ-

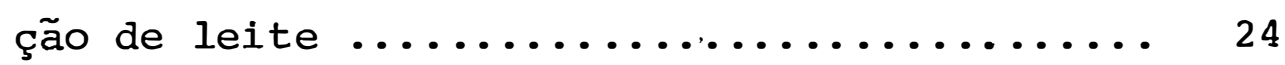

7 Consumo diārio médio de MS total .......... 29

8 Análise da variância dos dados de consumo

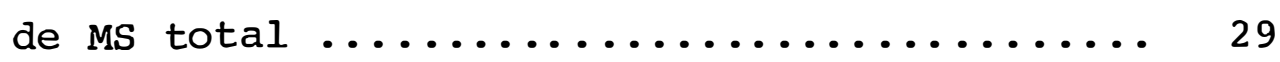

9 Consumo diário médio de MS total por unidade de peso metabólico ................ 32 
10 Análise da variância dos dados de consumo de MS total por unidade de peso metabólico .... 32

11 Consumo diário médio de volumoso por unidade de peso metabólico ................ 35

12 Análise da variância dos dados de consumo

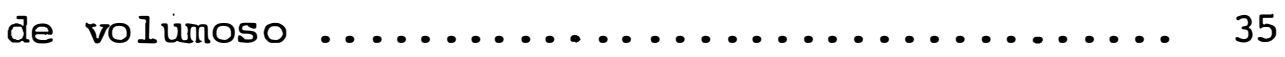

13 Consumo diárírio médio de concentrado por unidade de peso metabólico .............. 36

14 Análise da variância dos dados de consumo

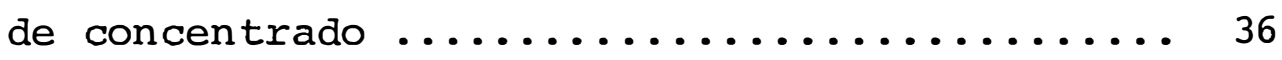

15 Consumo diário médio de MS total em porcentagem do peso vivo ................... 41

16 Análise da variância dos dados de consumo de MS total em porcentagem do peso vivo ......

17 Pesagens e variação do peso metabölio por tratamento .. 44

18 Variação no peso metabōlico .............. 46

19 Análise da variância dos dados de variação do peso metabólico ................. 46 
vii

TABELA NO

pàgina

20 Teor de gordura do leite ................ 49

21 Análise da variância dos dados de gordura ... 50

22 Teor do E.S.T. do leite ................. 54

23 Análise da variância dos dados de E.S.T. ... 55

24 Teor de E.S.D. do leite ................. 57

25 Análise da variância dos dados de E.S.D. ... 58

26 Densidade do leite ................... 60

27 Análise da variância dos dados de densidade • 61

28 Indice de acidez do leite .............. 63

29 Análise da variância dos dados de acidez ... 64

30 Médias de produção de leite, consumo diário de MS e variação ponderal por tratamento ....

31 Médias das características do leite por tra

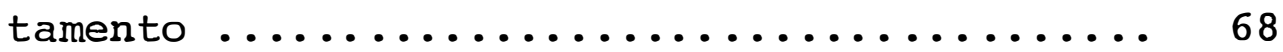


1 Produção total de leite em função do nível

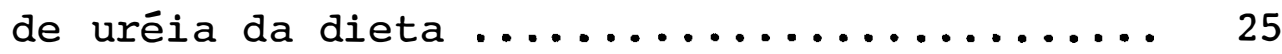

2 Ingestão de MS total em função do nível de uréia da dieta ......................... 30

3 Ingestão de MS de concentrado em função do nível de uréia da dieta ................. 38

4 Variação na média do PV por tratamento ..... 45

5 Variação no peso metabōlico em função do nível de uréia da dieta ............... 47

6 Teor de gordura do leite em função do nIvel de uré̀ia da dieta ................. 51

7 Densidade do leite em função do nível de

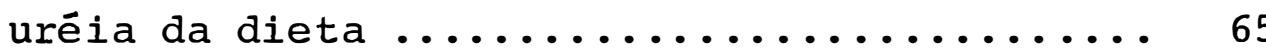




\title{
PRODUÇÃO DE LEITE EM CAPRINOS ALIMENTADOS \\ COM NIVEIS CRESCENTES DE URÉ IA
}

\author{
AUTOR : \\ LUIZ EDUARDO DOS SANTOS \\ ORIENTADOR: MAX LĀZARO VIEIRA BOSE
}

\section{RESUMO}

O presente trabalho foi conduzido com o objetivo de estudar a possibilidade de utilização da uréia na adequa ção do nível de nitrogênio da dieta de caprinos em lactação, bem como observar o efeito da substituição parcial do nitrogênio proteico (NP) da dieta por nitrogênio-não-protéico na produção de leite e em suas características físico-químicas.

O experimento foi conduzido em Itapetininga, SP, no Posto de Ovinos e Caprinos do Instituto de Zootecnia.

Foram utilizadas 20 cabras da raça Anglo-nubiana de terceira e quarta lactação, as quais permaneceram confinadas em baias indiviđuais durante todo o período experimental de 8 semanas.

Os tratamentos consistiram em 4 dietas completas (ponta de cana + concentrado), isoenergéticas e isoproteicas, com níveis crescentes de uréia, de maneira a se obter 0,10 , 20 e $30 \%$ de substituição da proteína digestível (PD) pelo equivalente em uréia. 
Para a avaliação do desempenho animal, dèntro de cada tratamento, foram determinados: a ingestão diária de matéria seca (MS), de volumoso e de concentrado; a variação no peso metabólico e a produção diária de leite. Também foram estudadas as variações na composição do leite, através de determinações do teor de gordura, extrato seco total (EST), extrato seco desengordurado (ESD), acidez e densidade, em três diferentes épocas de amostragem (início, meio e fim do pe ríodo experimental).

A substituição do NP da dieta por NNP levou a uma redução linear e significativa $(P<0,01)$ na produção de leite.

A ingestão de MS total, por unidade de peso metabólico, não variou em função do nível de uréia. Entretanto, foi observada tendência de aumento na ingestão de MS de volumo so, enquanto houve diminuição significativa $(P<0,01)$ na ingestão de MS de concentrado. Os níveis de ingestão de MS to tal (75 a $79 \mathrm{~g} \mathrm{MS} / \mathrm{kg} \mathrm{PV}^{0,75}$ ) foram considerados baixos em todos os tratamentos.

A variação no peso metabólico diminuiu significativamente $(P<0,01)$, com o aumento do nível de uréia. No entanto, não houve diferença significativa entre o tratamento sem uréia e o de menor nível de substituição, quanto a ganho de peso, embora este tendesse a ser inferior.

Quanto às características do leite, observou-se 
aumento linear e significativo $(P<0,01)$ no teor de gordura em relação aos níveis de uréia, sendo também observadas diferenças..entre as amostragens, com maior teor de gordura na últí ma. O EST não variou nem em função dos níveis de uréia, nem das amostragens, enquanto que O ESD variou somente em função da amostragem $(P<0,01)$. A densidade do leite não variou em função da amostragem, mas aumentou de maneira significativa $(P<0,01)$ em relação ao aumento do nível de uréia, enquanto que a acidez do leite não foi afetada por nenhuma das variáveis estudadas.

Concluiu-se que a utilização da uréia na dieta de caprinos em lactação prejudicou sensivelmente 0 desempenho leiteiro dos animais em quaisquer dos níveis utilizados; a variação ponderal também foi prejudicada sensivelmente, menos no menor nível de substituição de NP por NNP. 


\title{
MILK PRODUCTION IN GOATS FED WITH INCREASING LEVES OF UREA,
}

\author{
AUTHOR : LUIZ EDUARDO DOS SANTOS \\ ADVISER: MAX LĀZARO VIEIRA BOSE
}

\section{SUMMARY}

This experiment was carried out to study the use of urea for goats to fit the nitrogen level of the diet to animal requeriments for milk production and study the effects of the partial substitution of protein nitrogen (PN) for nonprotein-nitrogen (NPN) in the milk production and milk physical and chemical characteristics.

The experiment was carried out in Itapetininga, SP, and were utilized twenty Anglonubian goats of third and fourth lactation, with similar weights and lactation stages. The animals were individually stall-fed during the expenimental period which lasted eight weeks.

Four approximately isonitrogenous and isoenergetic rations with increasing levels of urea replacing the PN sources so that to attain $0,10,20$ and $30 \%$ of replacing of the digestible nitrogen for urea equivalent were fed to the animals. The variables used to evaluate the treatments were: daily milk production, daily roughage and concentrate 
(dry matter basis) intakes, total metabolic weight variation and milk composition. The milk composition was determined through the analyses of the fat content, total solids (TS), solids-not-fat (SNF), acidity and density. These analyses were made in the begining, in the middle and in the end of the experimental period.

The substitution of the PN for NPN resulted in significant $(P<0,01)$ decrease in milk production.

The total dry-matter (DM) intake based on the unity of metabolic weight was not altered by the levels of urea but a increasing tendency of roughage dry-matter intake and a significant $(P<0,01)$ decrease of concentrate dry-matter intake were observed. The level of total dry-matter intake ( 75 to $79 \mathrm{~g} \mathrm{DM} / \mathrm{kg}$ Body Weight ${ }^{0,75}$ ) was considered low in all the treatments.

The metabdlic weight variation decreased significantly $(P<0,01)$ with the increases of urea level being negative in the largest level of PN substitution. The metabolic weight gain in the smallest urea level was lower than in the treatment without urea but did not differ statistically.

As to milk characteristic, a linear and significant $(P<0,01)$ increase in the fat content related to the increase of the urea level was observed. Differences among the three sampling of milk were observed being the fat content of the third sampling the highest $(P<0,01)$. The TS 
and the acidity did not show variation related to the urea level or order of sampling. The milk density did not vary with the order of sampling but increase significantly $(P<0,01)$ with the increase of the urea level whereas SNF content was altered only by the order of sampling being the third value higher than the others $(P<0,01)$.

It was concluded that the utilization of urea in milk goats diet decreased significantly the milk performance in all the levels utilized but dit not affect significantly the weight variation in the lowest level of replacing of $\mathrm{PN}$ for $\mathrm{NPN}$ - 


\section{INTRODUCÃO}

A caprinocultura, na região Centro-Sul do País, é caracterizada por criatórios de pequeno porte, geralmente com menos de cincoenta animais, criados em regime de semi-esta bulação ou estabulação total. As instalações utilizadas normalmente são rústicas e de baixo custo, também a mão-de-obra apresenta baixo custo, visto ser geralmente familiar e normalmente infantil. Assim, entre as principais componentes : do custo de produção de leite e carne com a espécie, a alimentação assume a maior importância.

A alimentação animal, nessas condições de produ ção, é baseada na utilização de gramíneas em pastejo direto ou através de corte e fornecimento em cochos ou manjedouras. A utilização de concentrados se resume no fornecimento de milho, principalmente sob a forma de "rolão" (milho triturado, em espiga, com palha), raramente enriquecido com pouco farelo de soja ou algodão. Esse tipo de dieta é deficiente princi palmente em proteínas, ficando bem abaixo das exigências de 
animais em lactação ou em crescimento.

O fornecimento de suplementos proteicos como o farelo de algodão, ou de soja, em quantidades suficientes, poderia adequar o nível de proteínas às exigências nutricíonais. No entanto, considerando-se a pequena margem de lucro, devido ao pequeno porte das criações, a elevação dos custos de produção nem sempre seria economicamente viável. Outro aspecto a. ser considerado é o potencial genético, para produção de leite e carne, normalmente pequeno demais para que haja respostas que justifiquem o incremento dos custos de produção.

Dentro deste contexto, é que se apresenta a possibilidade de utilização de outras fontes de nitrogênio não convencionais, como a uréia, o biureto e o sulfato de amônia entre outras, que seriam alternativas ao emprego dos farelos proteinosos quando o custo destes fosse elevado.

Este trabalho visa estudar a possibilidade de utilização da uréia na adequação do nível de nitrogênio na die ta de caprinos em lactação, observando-se o efeito da substitui ção de fontes de nitrogênio proteico (NP) por uréia, como fonte de nitrogênio não proteico (NNP), sobre a ingestão de matēria seca (MS), sobre a produção e sobre as características físico-químicas do leite. 


\section{REVISÃO DE LITERATURA}

Frequentemente a uréia tem sido apontada como alternativa para a substituição das tradicionais fontes de proteína, quando o preço destas eleva-se em demasia. Segundo STANGEL (1967), a uréia tem sido utilizada, em vārias regiões do mundo, na alimentação de ruminantes, com resultados satisfá tórios como substituto parcial do NP, sem prejudicar significativamente o desempenho animal, desde que o fornecimento seja cuidadoso: No entanto, se não existem dúvidas quanto à possi bilidade de substituição de parte das fontes de NP por fontes de NNP em dietas de ruminantes, elas existem quanto ao nível de substituição e ao efeito sobre o desempenho animal, bem como sobre características dos produtos obtidos - carne, leite e lã -, quando são considerados não só a variação das exigências nutricionais em razão da idade e do estado fisiológico do animal (produção ou não), mas também a disponibilidade de NP na dieta.

A suplementação com fontes de NNP tem mostrado 
melhora do desempenho com rēlação à utilização exclusiva do volumoso de baixa qualidade, mas tem sido sempre inferior ao desempenho obtido com fontes de NP de boa qualidade, conforme observaram CHICCO et alii (1972) e RUSCH e TOTUSEK (1976).

Segundo SMITH (1969), e ainda HOGAN e WESTON (1969), aproximadamente 60\% da proteína da dieta é degradada pelos microrganismos do rúmen, a peptídeos, aminoácidos e amô nia, os quais são utilizados na síntese de proteína microbiana. Assim, se a dieta é rica em proteínas de elevado valor biológi co, a ação dos microrganismos sobre a proteína pode ser considerada negativa. No entanto, em dietas com baixo teor protei co, où com proteínas de baixo valor biológico, a ação dos microrganismos será significativamente benéfica, pois irá transformar proteína de baixa qualidade em proteína microbiana, de melhor valor biológico, ou irá elevar o nível de proteína disponível ao animal, desde que haja disponibilidade de outras fontes de $\mathrm{N}$, como $\mathrm{O} \mathrm{N}$ reciclado no organismo via saliva ou corrente sanguínea, ou ainda fontes de NNP, desde que não haja limitação de energia, vitaminas e minerais, conforme citam SMITH et alii (1960), MC LAREN et alii (1965) e CHALUPA (1968).

A utilização de fontes de NNP, como a uréia, visa substituir a proteína no fornecimento de amônia para os microrganismos, ficando o NP principalmente na forma de peptídeos e aminoácidos, para aproveitamento direto pelo animal. DEVENDRA (1980) cita que 70 a 75\% do total da PB (proteína bruta) pode ser substituida por fontes de NNP como uréia ou 
biureto, possibilitando a redução do custo de alimentação quan do o diferencial de preços for elevado.

Os caprinos, assim como os demais ruminantes, têm condições de utilização do NNP, conforme citam FUJIHARA e TASAKI (1975), os quais observaram que a administração de níveis crescentes de uréia no abomaso de caprinos não afetou o nível de $\mathrm{N}$ fecal, indicando que praticamente toda a uréia foị absorvida. Por outro lado, a digestibilidade da PB aumentou linearmente com a infusão de uréia, e, apesar de haver também um aumento significativo na excreção de $\mathrm{N}$ urinário, verificoụ se aumento na retenção de $\mathrm{N}$, confirmando a viabilidade de utilização da uréia por caprinos.

$$
\text { MORAND-FEHR e SAUVANT (1980) observaram que }
$$

os caprinos parecem sensíveis à variação das fontes de proteína da dieta. No entanto, eles utilizam o NNP relativamente bem, e esse aproveitamento melhora quando há quantidade elevada de energia disponível na forma de carboidratos solúveis.

EMMANUEL e EMADY (1978) não observaram diferenças entre caprinos e outros ruminantes quanto à capacidade de aproveitamento de NNP avaliada através da taxa de degradação de uréia e do nível de uréia no plasma.

$$
\text { Muitos trabalhos tem sido conduzidos visando }
$$
estudar a utilização da uréia para produção de leite. Contudo, ainda existem dúvidas quanto a sua viabilidade com caprinos de alta produção. Segundo HELMER e BARTLEY (1971), é possí- 
vel a utilização da urëia com animais de baixa produção, e que embora o valor biológico observado para vārias fontes de $\mathrm{N}$ testadas varie consideravelmente, o desempenho de animais de alta produ ção tem sido sempre melhor com fornecimento de $\mathrm{NP}$ do que com NNP.

FREITAG et alii (1968), comparando o efeito de dois níveis de uréia na ração de bovinos $(30$ e $70 \%$ do $\mathrm{N}$ total da dieta), não observaram diferenças no balanço de $\mathrm{N}$; na digestibilidade da energia; na produção de ácidos graxos volāteis no rúmen e na concentração de uréia no sangue, bem como não obser varam variação na concentração de aminoácidos livres no rúmen. Entretanto, quando todo o NP dos tratamentos com uréia foi forneci do pelo milho, ao invés do farelo de soja, observou-se redução no ganho de peso e na concentração de valina, isoleucina, lisina, leucina, fenilalanina, alanina, tirosina e ác. glutâmico livres no rúmen, mostrando a importância de se ter parte do $\mathrm{N}$ da dieta proveniente de fontes de NP de bom valor nutritivo.

KONDOS e MUTCH (1975) observaram efeito negativo da adição de uréia a una dieta básica, fornecendo 5.0\% do total de $\mathrm{N}$, sobre o desempenho de bovinos. O mesmo foi observado por KONDOS (1975) com o biureto, em níveis de 0,8 a $2,5 \%$ do MS total.

SREEMANNARAYANA e MAHAPATRO (1982), estudando a possibilidade de uso de NNP para caprinos em ćrescimento , compararam três dietas: com NP à base de proteina de amendoim, com NP à base de proteína de amendoim aquecido e com uréia sub tituindo $35 \%$ do equivalente em proteína. Não foram observa 
das diferenças significativas no ganho de peso dos 4 aos 6 meses. Não obstante, o tratamento com farelo aquecido apresentou tendência a proporcionar maior ganho de peso, enquanto que com uréia apresentou o pior desempenho, não sendo observada ne nhuma modificação na digestibilidade da MS, proteína bruta, celulose ou da fibra detergente ácido, nem no balanço de N .

BHANDARI et alii (1973) não observaram diferenças no desempenho de caprinos com dieta na qual $30 \%$ da $P B$ foi substituída pelo equivalente em uréia, porém houve um acréscimo de $11 \%$ no ganho de $\mathrm{PV}$ (peso vivo), em resposta à adição de enxofre na dieta.

BHATTACHARYA (1980) cita trabalho conduzido em Chipre, no qual se comparou uma ração com 15\% de farelo de soja com uma ração isoproteica contendo $2 \%$ de uréia substituindo totalmente o farelo de soja, destinada a cabritas em crescimen to. Não foram observadas diferenças significativas no crescimento, apesar do grupo alimentado com uréia apresentar conversão significativamente menor. Por outro lado, MBA et alii (1974), comparando uréia com farelo de torta de amendoim como fonte de $\mathrm{N}$ para cabritas, observaram crescimento mais rápido no lote alimentado com uréia.

Se para crescimento e engorda a utilização de uréia como substituto parcial de fontes de proteína não tem apresentado redução significativa no desempenho, o mesmo não tem sido observado para produção de leite, onde $\circ$ desempenho 
de caprinós,com dietas nas quais a uréia substitui parte da proteína, em vários trabalhos, inferior a daqueles suplementados exclusivamente com NP.

VAN HORN (1980) comenta que a utilização de

NNP na alimentação de caprinos leiteiros pode apresentar resul tados positivos, desde que sejam observados os seguintes pontos:

- A uréia, ou o equivalente em outras fontes de NNP, não deve ser fornecida em níveis superiores a 1\% do total de MS da dieta.

- É necessário que parte das necessidades em N seja atendida através de NP, para assegurar fornecimento de aminoácidos específicos aos microrganismos do rúmen, e mesmo ao hospedeiro.

- A uréia é mais efetiva quando incluída em dietas com baixo teor em proteínas ou com fontes de proteína de baixa solubilidade como a do milho, do farelo de soja ou de algodão.

- o fornecimento da uréia não deve ser superior a $1 \mathrm{~g} / \mathrm{Kg}$ de PV/dia.

ISLAM et alii (1977) estudaram a eficiência do aproveitamento de $\mathrm{N}$ em caprinos alimentados com dietas com diferentes níveis de substituição de NP por NNP $(0,25,35$ e 45\%), equivalentes a $0 ; 5,2 ; 7,2$ e 9,2 g de uréia/dia. 0 maior nível de retenção foi obtido com dieta de 25\% de NNP. Não se observou nenhum efeito negativo mesmo ao nível de 45\% 
de NNP, o qual se igualou à dieta só com NP em termos de retenção de $\mathbf{N}$.

SINGHAL e MUDGAL (1981), comparando dietas com NP, com dietas contendo uréia ou biureto como substituto de fontes de NP para caprinos, observaram que a adição de NNP levou a aumento na ingestão de MS , o que foi atribuído ao aumento da velocidade de passagem do alimento pelo trato intes tinal. Já RAY e PANDEY (1980) não conștataram aumento na atividade intestinal, mas observaram acentuado aumento na digestibilidade da proteína nos tratamentos com NNP, e concluiram que é possível a substituição de até $50 \%$ da proteína pelo equivalente em uréia ou biureto, sem qualquer efeito adverso sobre o crescimento ou a utilização dos nutrientes.

Segundo CHALUPA (1968), em dietas com baixo teor em proteínas, o baixo nível de $\mathrm{N}$ da digesta é o principal fator limitante da taxa de fermentação no rúmen e da velocidade de passagem do alimento pelo trato gastro-intestinal. E 0 efeito do fornecimento suplementar de $N$, seja proteico ou não, sobre o nível de ingestão de alimento é atribuído ao au-mento de fermentação e na velocidade de passagem do alimento pelo trato digestivo.

KRISHNA REDDY e NAIR (1972), comparando dietas com NP e com 25\% de NNP para caprinos, não observaram qualquer efeito adverso sobre os processos normais de fermentação ruminal e produção de ācidos graxos voláteis, nem observaram eleva ção excessiva do nỉvel de amônia no rúmen. 
HAENLEIN (1978) cita a possibilidade de utiliża ção econômica da palha de arroz enriquecida com uréia e melaço, na alimentação de cabras estabuladas, e recomenda um máxiximo de $0,6 \%$ de uréia no total de MS da ração. Segundo SNGHAL (1978), tanto a uréia como o biureto são alternativas válidas na alimentação de caprinos, sendo que a substituição de $50 \%$ da proteína digestível, pelo equivalente em uréia ou biureto, não causou modificação na produção nem na composição do leite, o que também foi observado por CAMPBELL et alii (1963) e SINGHAL e MUDGAL (1980b). Por outro lado, alguns autores como HUBER e SANDY (1965), CHALUPA (1968), VAN HORN e MUDD (1971) , HUBER (1975) , KERTZ e EVERETT (1975) e RINDSIG (1977), citam a redução no consumo de MS como causa de possíveis quedas na produção de leite em animais de elevada produtividade. Porém, SINGHAL e MUDGAL (1980a) e SINGHAL e MUDGAL (1981) observaram aumentos na ingestão de MS com dietas contendo uréia.

O efeito da adição de uréia na dieta. sobre a composição do leite também tem sido alvo de muitos trabalhos, com resultados bastante variáveis.

O teor de gordura aumenta, segundo : VIRTANEN (1967), CONRAD E HIBBS (1968) e GONZALEZ et alii (1982), sendo as causas mais citadas: a variação na proporção entre ácidos graxos voláteis no rúmen; a variação na digestibilidade dos nutrientes da dieta, com aumento da digestibilidade da fração fibrosa, e mesmo a redução n'o volume total do leite pro 
duzido, aumentando a porcentagem de participação da fração' gor dura. Todavia, outros autores, como VAN HORN e JACOBSON (1971)， DEVENDRA (1980)，SINGHAL e MUDGAL (1980b) e GONZALEZ et alii (1982), não observaram variações no teor de gordura nem das demais frações do leite como extrato seco total (EST) e extrato seco desengordurado (ESD).

VIRTANEN (1967) menciona ser possível o aumento da densidade do leite, em razão do formecimento de uréia estar ligado ao aumento no teor de proteína do leite.

RYS (1967) observou aumentos significativos do Indice de acidez do leite de animais que receberam uréia.

Por outro lado, autores como SIRRY e HASSAN (1954)， VAN HORN e JACOBSON (1971)， DEVENDRA (1980), SINGHAL e MUDGAL (1980b) e GONZALEZ et alii (1982) não observaram variações seja na densidade, seja na acidez do leite, como consequência da uréia na dieta. 


\section{MATERIAL E MÉTODOS}

O presente trabalho foi conduzido em Itapetinin ga, SP, no Posto de Ovinos e Caprinos (POC) do Instituto de Zootecnia, da Secretaria da Agricultura e Abastecimento do Estado de São Paulo, o qual está situado na região sul do estado, a $23^{\circ} 35^{\prime}$ de latitude sul e $48^{\circ} 02^{\prime}$ de longitude oeste, com alti. tude de $636 \mathrm{~m}$. O solo é do tipo Latossol Vermelho Escuro-orto e o clima, segundo BLAIR (1942), pode ser classificado como subtropical do tipo savana, com chuvas irregulares durante 0 ano, apresentando média anual de $1.150 \mathrm{~mm}$ de precipitação pluviométrica. A temperatura média anual da região é de $19^{\circ} \mathrm{C}$, sendo a média das temperaturas máximas de $23^{\circ} \mathrm{C}$ e a média das temperaturas mínimas de $8,3^{\circ} \mathrm{C}$.

Foram utilizadas 20. cabras da raça Anglo-nubiana de terceira e quarta lactaçã், separadas de plantel maior, procurando-se obter um lote de animais com pesos uniforme: e da mesma fase de lactação (início). 
Os animais selecionados permaneceram, inicialmente, em pastagens de capim pangola (Digitaria decumbens , Stent), recebendo suplementação de concentrado à base de farelo de soja, farelo de algodão e milho, em espiga, triturado. Além disso, os animais receberam cana picada, à vontade, após recolhimento em baias coletivas à noite. Esse esquema perdu rou até a instalação do experimento, que ocorreu quando os an mais ultrapassaram o pico de lactação, ou seja, 45 a 60 dias após a parição. A partir de então, os animais, após receberem tratamento anti-helmíntico, foram colocados em baias individuais, localizadas em instalação coberta, abrigadas de ventos fortes e com boas condições de iluminação e ventilação, on de permaneceram confinados até o final do experimento. Semanalmente os animais foram soltos por 2 a 3 horas, em curral com piso de terra batida, para se exercitarem.

As baias individuais possuiam bebedouro e cocho externos, de maneira a se impedir contaminação dos alimen tos e da āgua. O piso era de ripado e suspenso, possibilitan do livre escoamento a fezes e urina.

No período inicial, de uma semana, foi oferecida uma única dieta (dieta pré-experimental), constituída de ca pim pangola cortado, cana picada e concentrado, e procurou-se adaptar os animais às instalações. Nessa fase o plantel foi separado em cinco grupos de quatro animais cada, conforme a pro dução de leite no período. 
Dentro de cada um desses grupos foram sorteados os quatro tratamentos, detalhados a seguir:

A - Dieta sem uréia (0\% de NNP) ;

B - Dieta com $5 \mathrm{~g}$ de uréia (10\% da PD substituída pelo equivalente em uréia) ;

C - Dieta com $10 \mathrm{~g}$ de uréia (20\% da PD substituída pelo equivalente em uréia) ;

D - Dieta com $15 \mathrm{~g}$ de uréia (30\% da PD substituída peic equivalente em uréia) .

As rações formuladas foram isonitrogenadas e isocalóricas, e a cada animal foram fornecidas diariamente $17 \mathrm{~g}$ de mistura mineral, visando-se atender às exigências estimaúas para as características médias iniciais:

- Peso vivo - $35 \mathrm{~kg}\left(14,38 \mathrm{~kg} \mathrm{PV}^{0,75}\right)$;

- Consumo diário de MS, conforme o ITOVIC (1982) $1,5 \mathrm{~kg} /$ cabeça $\left(104 \mathrm{~g} / \mathrm{kg} \mathrm{PV}{ }^{0,75}\right)$;

- Produção prevista de leite - 1,5 kg/dia;

- Necessidade proteica, conforme RINDSIG (1977) $125 \mathrm{~g}$ PD / cab / dia (sendo 1,4 g/dia/kg de PV paris manutenção e $51 \mathrm{~g}$ PD / kg de leite produzido) ; 
- Necessidade energética, conforme RINDSIG (1977) $971 \mathrm{~g}$ NDT / cab / dia (sendo 13,6 g/dia/kg de PV para manutenção e $330 \mathrm{~g} / \mathrm{kg}$ de leite com 4\% de gordura) ;

- Necessidades diárias em minerais, conforme o HARRIS $(1980)-\mathrm{Ca}-11,5 \mathrm{~g} ; \mathrm{S}-1,5 \mathrm{~g} ; \mathrm{P}-5,5 \mathrm{~g} ; \mathrm{NaCl}-$ $-4,0 \mathrm{~g}$

Os ingredientes utilizados na formulação das raçōes experimentais foram analisados no Laboratório Central do Instituto de Zootecnia, em Nova Odessa (Tabela 1), segundo as técnicas descritas pela A.O.A.C. (1965). Com base nessas anālises, foram formuladas as quatro rações (Tabela 2) utiliza das no trabalho.

Tabela 1. Composição química-bromatológica dos ingredientes da dieta.

\begin{tabular}{|c|c|c|c|c|c|c|c|c|}
\hline \multirow{2}{*}{ INGREDIENTES } & \multirow{2}{*}{$\begin{array}{c}\text { M.S. } \\
8\end{array}$} & \multicolumn{7}{|c|}{ \% na M.S. } \\
\hline & & $\mathrm{PB}$ & $\mathrm{PD}=$ & $\mathrm{NDT}^{\mathrm{a} /}$ & $\mathrm{Ca}$ & $\mathrm{P}$ & $S$ & $\mathrm{NaCl}$ \\
\hline Farelo de soja & 90,00 & 45,00 & 41,40 & 79,50 & 0,35 & 0,64 & 0,43 & -- \\
\hline Farelo de algodão & 92,00 & 21,00 & 15,10 & 76,60 & 0,15 & 1,20 & 0,21 & -- \\
\hline Milho desintegr. & 87,50 & 8,60 & 4,90 & 73,20 & 0,01 & 0,30 & 0,10 & - \\
\hline $\begin{array}{l}\text { Ponta de Cana } \\
\text { (terço final } \\
\text { da planta) }\end{array}$ & 26,50 & 2,10 & 0,90 & 65,90 & 0,06 & 0,11 & 0,05 & -- \\
\hline Uréia & 100,00 & 262,00 & 262,00 & -- & - & - & -- & -- \\
\hline Mistura mineral & 100,00 & -- & -- & $-\infty$ & 63,70 & 12,30 & 1,00 & 23,00 \\
\hline
\end{tabular}

af Estimados com base nas Tabelas de Composição de Alimentos da América Latina (McDOWELL et alii, 1974). 
Tabela 2. Composição ponderal e percentual das raçöes:

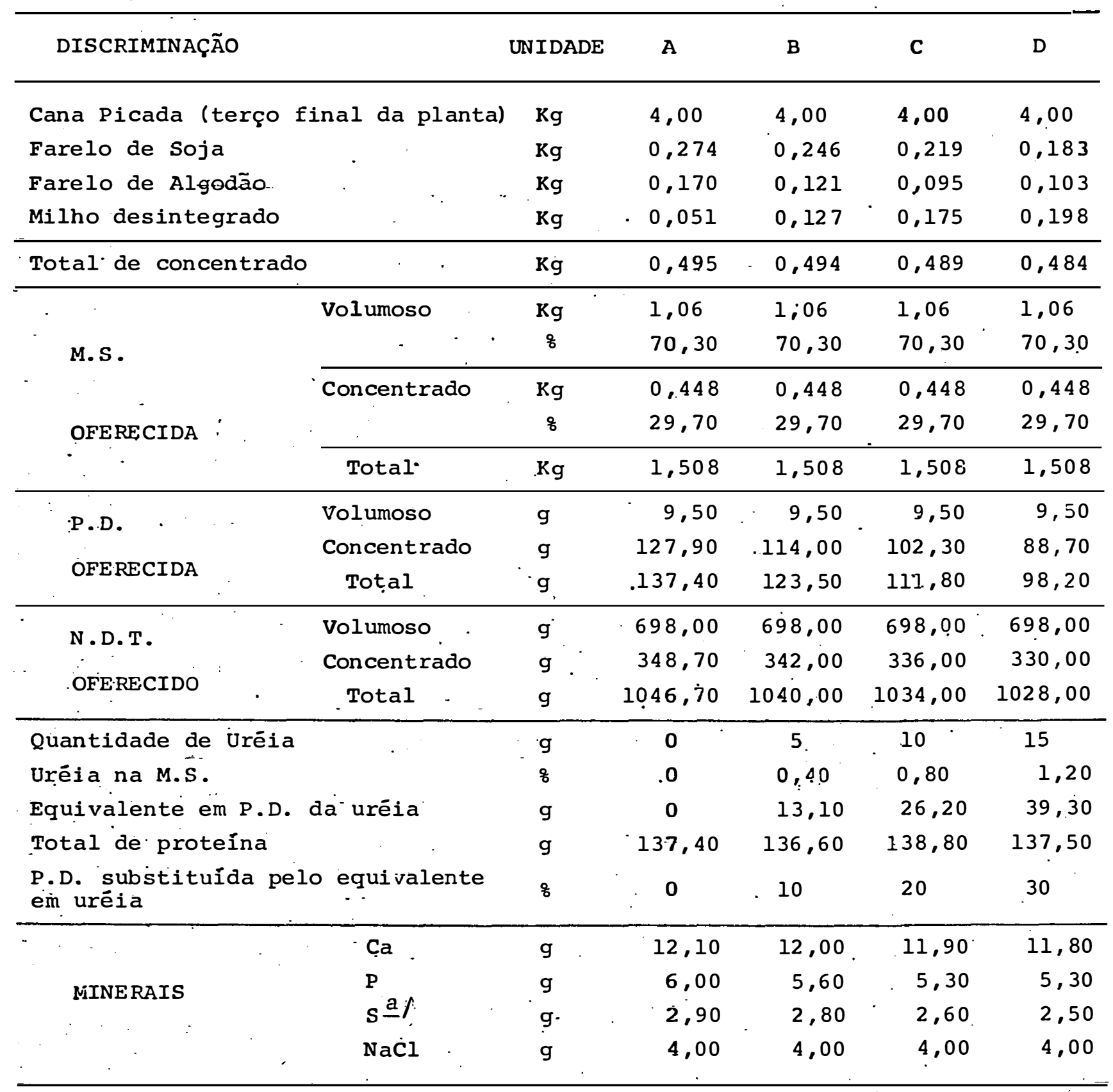

a/ A relação $\mathrm{S} / \mathrm{N}$ foi mantida entre 1/10 e 1/15. 
Após a semana de adaptação às instalações, os animais começaram a ser adaptados, gradativamente, às dietas experimentais (Tabela 3), de maneira a se evitar ocorrência de intoxicações. O período de adaptação às dietas foi de quatro semanas, a partir do qual se iniciou a coleta de dados.

Tabela 3. Esquema de adaptação dos animais à dieta.

\begin{tabular}{|c|c|c|c|}
\hline Semana & Grupo de Animais & Dieta & Objetivo \\
\hline la. & Todos $(A, B, C$ e $D)$ & $\begin{array}{l}\text { Pré- } \\
\text { Experimental }\end{array}$ & $\begin{array}{l}\text { Adaptação às } \\
\text { instalações }\end{array}$ \\
\hline $2 a$. & B, C e D & $\begin{array}{l}\text { A } \\
\text { B }\end{array}$ & \multirow{3}{*}{$\begin{array}{l}\text { Adaptação } \\
\text { às } \\
\text { Rações } \\
\text { Experimentais }\end{array}$} \\
\hline 3a. & $\begin{array}{c}A \\
B \\
C \text { e D }\end{array}$ & $\begin{array}{l}\text { A } \\
\text { B } \\
\text { C }\end{array}$ & \\
\hline $4 a$. & $\begin{array}{l}\text { A } \\
B \\
C \\
D\end{array}$ & $\begin{array}{l}\text { A } \\
B \\
C \\
D\end{array}$ & \\
\hline
\end{tabular}

o período de coleta foi de oito semanas, durante as quais foi feita uma única ordenha diária às 7:00 hs, quando era fornecido metade do concentrado. Uma hora após a oferta do concentrado, era fornecida metade do volumoso $(2 \mathrm{~kg})$, que permanecia à disposição dos animais até às 15:00 hs, quan do era servida a metade final do concentrado, o qual ficava à 
disposição por mais uma hora,..seguindo-se 0 oferecimento do restante do volumoso, para ser consumida até a manhã do dia seguinte.

As sobras de concentrado e de volumoso, correspondentes a cada animal, eram recolhidas separadamente em sa cos plásticos. Essas sobras eram pesadas diariamente, sendo que da sobra de volumoso, assim como do volumoso oferecido, eram retiradas duas amostras por semana, constituindo uma amostra compostạ para determinação do teor de MS, permitindo a avalia ção do consumo diário de MS . A oferta diária de concentrado, baseou-se no consumo de volumoso do dia anterior, proporcionan do-se uma relação constante de $70 \%$ de volumoso e $30 \%$ de concentrado, com base na MS .

Os parâmetros determinados para avaliação d desempenho dos animais dentro de cada tratamento foram:

- Produção diária de leite ;

- Ingestão diária de M.S. ;

- Variação no peso metabólico animal ;

- Variações na composição do leite, avaliadas através de análises do teor de gordura, sólidos totais, sólidos desengordurados, densidade e acidez .

Os animais foram pesados na separação inicial do plantel e depois no início, meio e fim do período experimen tal. O peso metabólico, no qual se basearam os dados de 
consumo de M.s. , foi calculado a partir da média dos três pesos do período experimental.

Foram realizadas três amostragens de leite para análise durante o período experimental: no início da primeira semana, no início da quinta semana e no final do período.

A determinação do teor de gordura foi feita com o auxílio do butirômetro de Gerber; a verificação da densidade foi feita através de termo-lacto-densímetro; o extrato seco total foi determinado com auxílio de disco comparador; o extrato seco desengordurado foi estimado pela diferença entre o extrato seco total e gordura, e a acidez foi determinada através do acidímetro de Dornic.

Para a análise estatística da produção de leite, ingestão de M.S. e variação ponderal, o delineamento experimen tal foi o de blocos inteiramente casualizados, com cinco repetições, sendo efetuada a decomposição da Soma de Quadrados dos Níveis de uréia nos componentes lineares, quadráticos e cúbicos, bem como obtida a equação de regressão de cada variável, em relação aos níveis de uréia.

A análise da variância obedeceu ao esquema: 


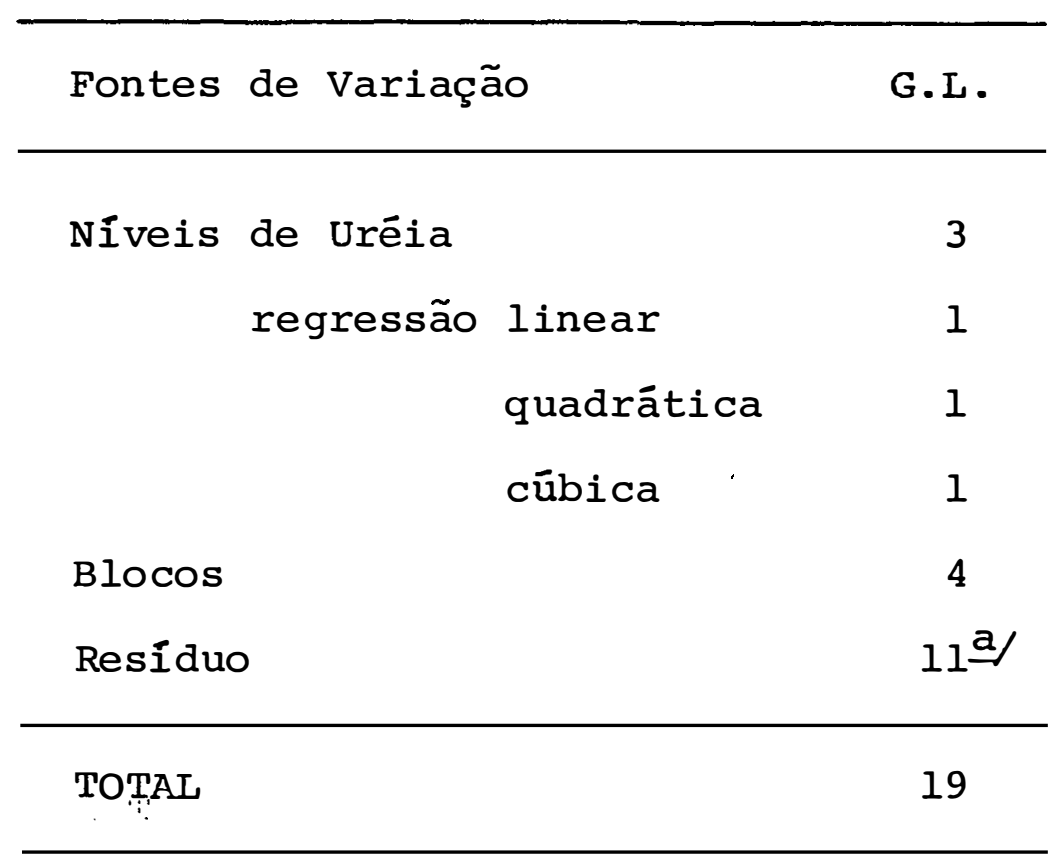

â/ Em razão da perda de uma das parcelas, cujos dados foram estimados conforme GOMES (1976), perdeu-se um grau de liberdade do resíduo.

Para o estudo das variáveis relativas às característiaas do leite, o delineamento foi o de blocos inteiramen te casualizados, em esquema fatorial $4 \times 3$, com quatro níveis de uréia e três amostragens de leite, com cinco repetições.

A análise de variância para cada parâmetro estụ dado, seguiu o esquema: 


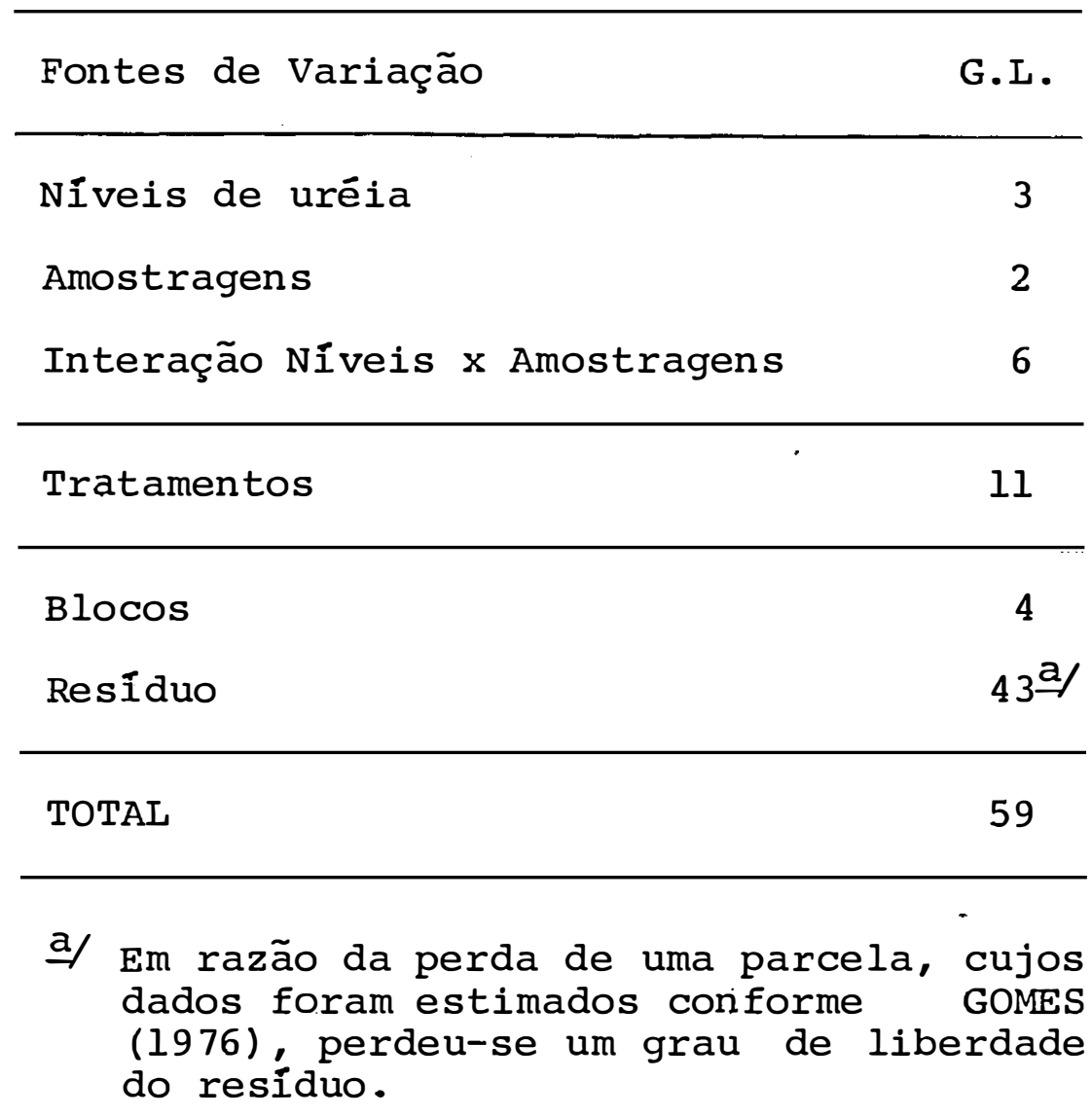

Nos casos em que a interação não foi significativa, procedeu-se a decomposição da Soma de Quadrados dos ní veis de uréia, nos componentes lineares, quadráticos e cúbicos, bem como foi obtida a equação de regressão de cada variável em relação aos níveis de uréia.

A distribuição dos animais nos blocos e traté... mentos de acordo com o PV inicial e com a produção de leit, na primeira semana do período pré-experimental, pode ser viéta na Tabela 4 . 


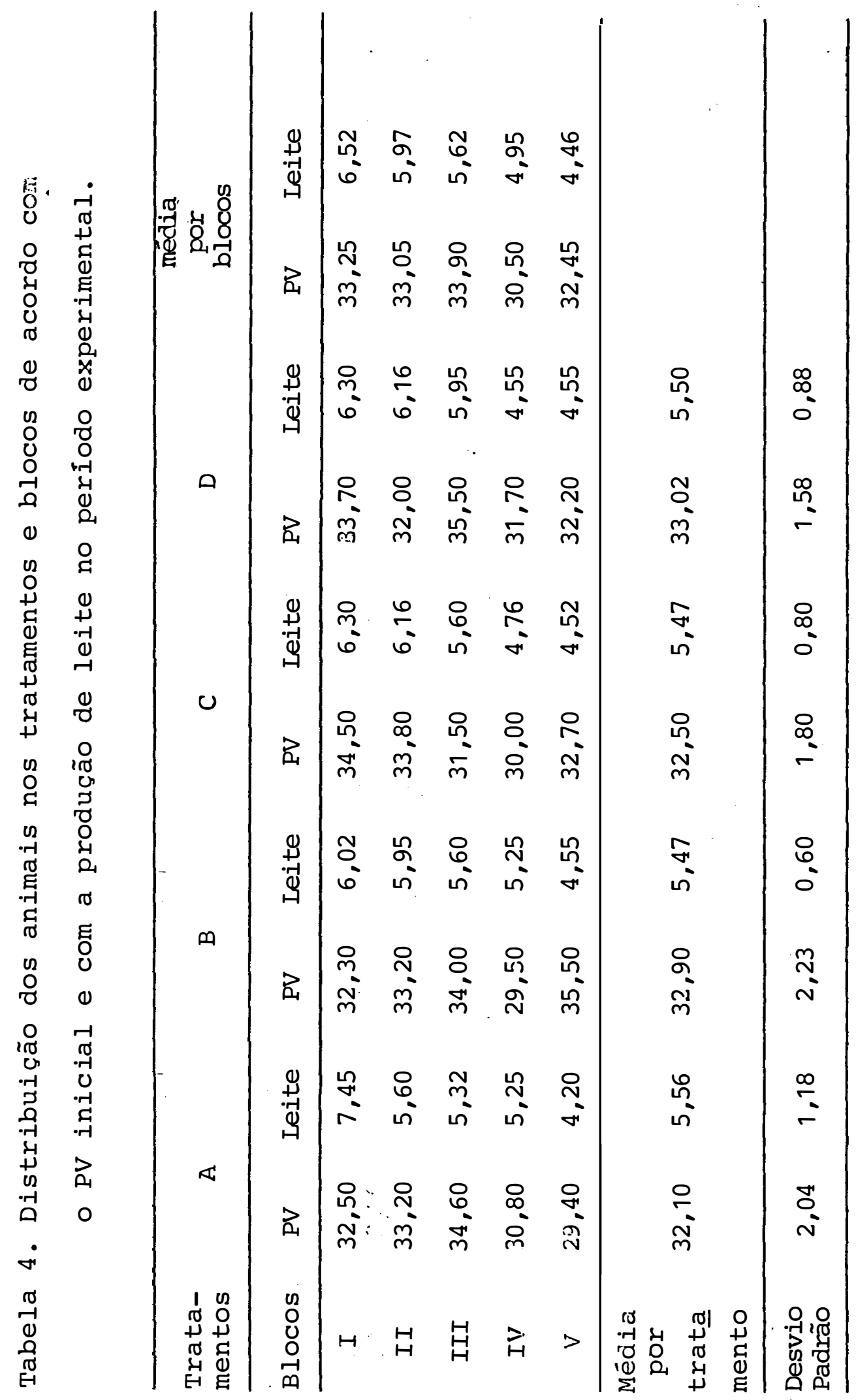


4. RESULTADOS E DisCUSSÃO

4.1. Produção de Leite

O desempenho leiteiro dos animais foi-avaliado através da produção total do período (Tabela 5).

A análise da variância (Tabela 6) indicou dife-renças significativas $(P<0,01)$ entre os tratamentos. A pro dução de leite diminuiu linearmente, de maneira significativa $(P<0,01)$, em relação ao aumento de uréia na dieta. A equa ção de regressão determinada foi:

$$
\mathrm{Y}=51,57-0,384 \mathrm{x}
$$

A curva referente. à equação de regressão da produção de leite, em relação aos níveis de uréia, é vista na Figura 1.

A substituição de NP por NNP levou a reduções 
Tabela 5. Produção total de Leite $(\mathrm{kg})$

\begin{tabular}{|c|c|c|c|c|c|}
\hline \multirow{2}{*}{ Blocos } & \multicolumn{4}{|c|}{ Tratamentos } & \multirow{2}{*}{$\begin{array}{l}\text { Média de } \\
\text { blocos }\end{array}$} \\
\hline & A & B & C & D & \\
\hline I & 70,45 & 48,08 & 46,20 & 47,90 & 53,16 \\
\hline II & 55,60 & 46,56 & 45,79 & 43,35 & 47,82 \\
\hline III & 50,57 & 44,84 & 46,60 & 42,20 & 46,05 \\
\hline IV & 46,41 & 42,43 & 40,88 & 37,05 & 41,69 \\
\hline $\mathrm{v}$ & 46,50 & 39,48 & 39,49 & 35,83 & 40,32 \\
\hline $\begin{array}{l}\text { Médias dos } \\
\text { Tratamentos }\end{array}$ & 53,91 & 44,28 & 43,79 & 41,27 & \\
\hline $\begin{array}{l}\text { Desvio } \\
\text { Padrão }\end{array}$ & 9,98 & 4,02 & 3,34 & 4,91 & \\
\hline
\end{tabular}

Tabela 6. Análise da variância dos dados de produção de leite.

\begin{tabular}{|c|c|c|c|c|}
\hline Fontes de Variação & G.L. & $S Q$ & $Q M$ & $\bar{F}$ \\
\hline Níveis de Uréia & 3 & 463,06 & 154,35 & $12,51 * *$ \\
\hline regressão linear & 1 & 368,76 & 368,76 & $29,88 * *$ \\
\hline \multirow{2}{*}{ regressão } & 1 & 63,04 & 63,04 & 2,92 n.s. \\
\hline & 1 & 31,26 & 31,26 & 2,53 n.s. \\
\hline Blocos & 4 & 450,57 & 112,64 & $9,13 * *$ \\
\hline Resíduo & 11 & 135,80 & 12,34 & \\
\hline TOTAL & 19 & 1049,43 & & \\
\hline
\end{tabular}

n.s. - Não significativo

* - Significativo ao nível de 5\% de probabilidade

** - Significativo ao nível de $1 \%$ de probabilidade

$\mathrm{CV}=8,15 \%$

$$
\mathrm{Y}=51,57-0,384 \cdot \mathrm{x}
$$




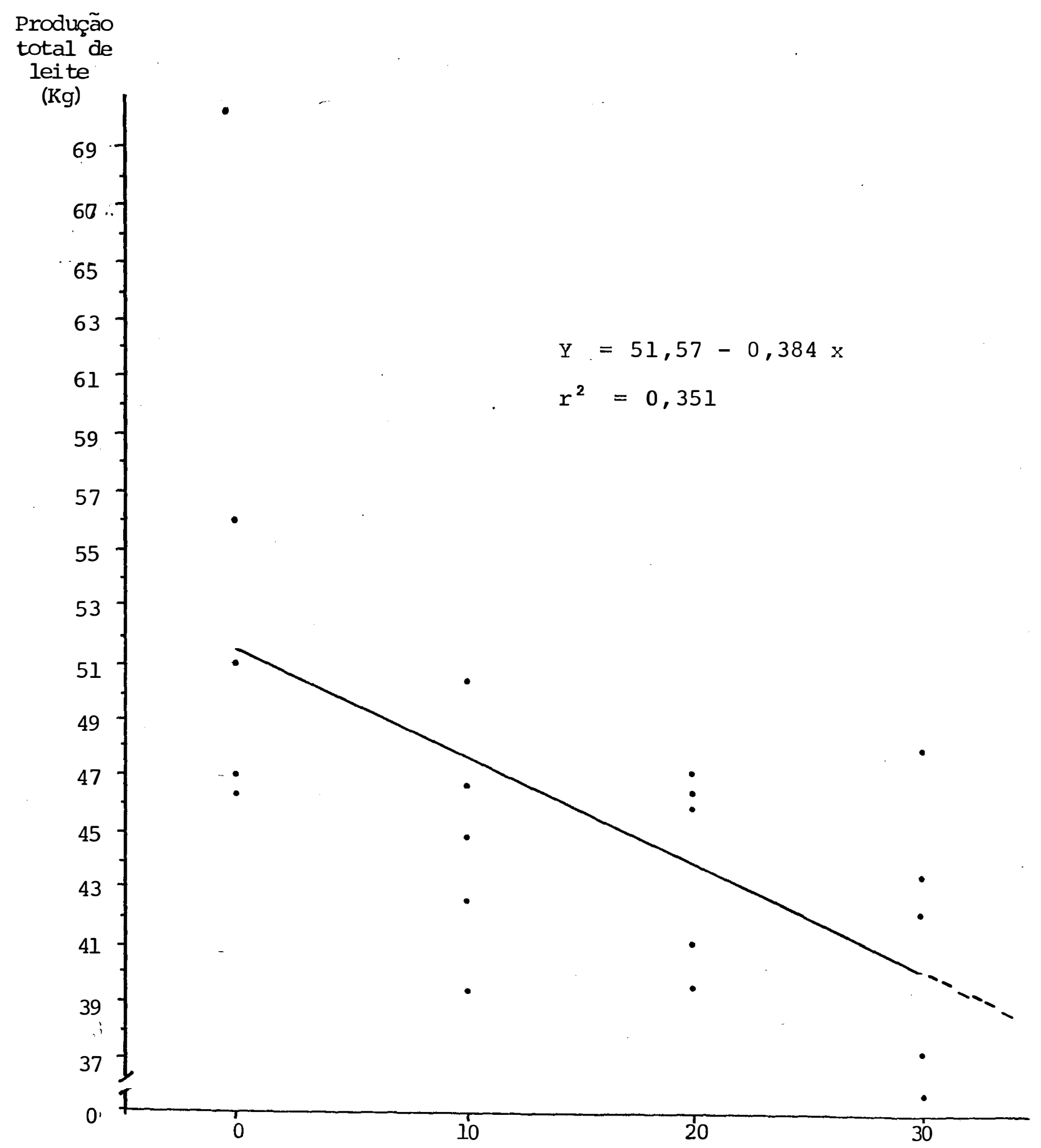

Niveis de uréia (\% de substituição da PD) Figura 1 - Proãução total de leite em função do nível de uréia da dieta. 
na produção total de leite de aproximadamente $17 \%, 19 \%$ e $23,5 \%$ " respectivamente, nos tratamentos B, C e D em relação à produção no tratamento A.

A redução na produção de leite, em animais cujas dietas tiveram parte das fontes de proteínas substituídas por uréia, também foi observada por vários pesquisadores. HEL MER e BARTLEY (1971) citam que, na maioria dos trabalhos, o desempenho leiteiro de animais de elevada produção tem sido melhor com o fornecimento de fontes de NP do que de NNP; no entanto, em animais de baixo nível de produção não se observaram efeitos negativos em razão da substituição parcial do NP da dieta por NNP - CONRAD e HIBBS (1968) também observaram diminuição na produção de leite, quando substituiram fontes de NP por uréia ( 35 a $40 \%$ ) na dieta de vacas de elevada produção.

Segundo HUBER (1975), existe uma correlação elevada e positiva entre produção de leite e ingestão de M.S., sendo que níveis elevados de substituição de NP por NNP podem levar a uma diminuição de ingestão de M.S. e a consequente diminuição na produção de leite. Também VAN HORN e MUDD (1971), trabalhando com vacas leiteiras, observaram redução na produção de leite e na ingestão de M.S., quando se substituiu o farelo de soja por uréia em níveis de 0,37 e 2,1\% da dieta, apesar de ter havido aumento na digestibilidade de M.S. e maior retenção de $\mathrm{N}$.

Segundo RYS (1967), a alteração na proporção en tre bactérias e protozoários, com diminuição dos ūltimos quan- 
do a uréia é fornecida, levaria a uma diminuição na quantidade de proteína digestível que chegaria ao abomaso, bem como no valor biológico da proteína microbiana, o que poderia afetar a produção de leite.

VAN HORN (1980) considera a deficiência de aminoácidos essenciais como possível causa da queda de produção de leite em caprinos de elevada produtividade, quando parte das exigências em $N$ é suprida pela uréia, pois a proteína microbiana do rúmem atenderia apenas às necessidades em aminoácidos essenciais suficientes para manutenção e baixos níveis de prodụ ção de leite.

Outros trabalhos não evidenciaram diferenças significativas na produção de leite, quando a uréia era respon sável por 25 a $50 \%$ do $\mathrm{N}$ total da dieta, como é o caso dos trabalhos de VIRTANEN (1967), HUERTAS et alii (1972) e SAUER et alii (1979), com bovinos; GONZALEZ et alii (1982), com ovinos, e ainda DEVENDRA (1967) , SINGHAL (1978) e SINGHAL e MUD GAL (1980b), com caprinos. Na maior parte desses trabalhos não houve diferenças significativas da ingestão nas dietas com e sem uréia. Já VAN HORN e JACOBSON (1971), trabalhando com bovinos, observaram aumentos de produção de leite e de ingestão de MS quando se substituiu parte do NP por NNP, com níveis de uréia de até 2,5\% da MS total da. dieta. Em razão dessa varía bilidade de respostas é que DEVENDRA (1980) realça a validade de utilização da uréia quando o diferencial de preços com outras fontes de $\mathrm{N}$ compensam a redução na produção. 


\subsection{Ingestão de Matéria Seca}

A quantidade de MS ingerida é um dos principais fatores determinantes do desempenho animal. De acordo com VAN SOEST (1982), as alterações observadas no consumo de dietas com uréia são devidas à estreita correspondência entre a ingestão de alimentos e fatores tais como palatabilidade, digestibilidade, atividade microbiana no rúmen e velocidade de passagem da digesta pelo trato intestinal, sobre os quais a uréia pọde influir. Os dados de ingestão diária de MS total, por animal, representada pela soma do consumo de MS de volumoso e MS de concentrado (Tabela 7), parecem confirmar essa influência.

A análise da variância (Tabela 8) indicou dife renças significativas $(P<0,01)$ entre os tratamentos, sendo que a ingestão de MS total diminuiu de maneira significativa $(P<0,01)$ e linear em relação ao aumento do nível de uréia na dieta. A equação de regressão obtida foi:

$$
\mathrm{Y}=1,15-0,005 \mathrm{x}
$$

A curva referente à equação de regressão é apresentada na Figura 2 .

Quando os dados de ingestão de MS foram tomados em relação ao peso metabólico (Tabela 9), verificou-se que o nível de uréia não afetou a ingestão de MS total, não sendo detectadas diferenças entre os tratamentos, conforme ficou eví 
Tabela 7. Consumo diário médio de MS tota'l (kg)

\begin{tabular}{|c|c|c|c|c|c|}
\hline \multirow{2}{*}{ Blocos } & \multicolumn{4}{|c|}{ Tratamentos } & \multirow{2}{*}{$\begin{array}{c}\text { Média de } \\
\text { blocos }\end{array}$} \\
\hline & A & B & C & D & \\
\hline I & 1,12 & 1,08 & 0,97 & 1,04 & 1,05 \\
\hline II & 1,23 & 1,12 & 1,16 & 0,93 & 1,11 \\
\hline III & 1,19 & 1,12 & 1,10 & 1,05 & 1,12 \\
\hline IV & 1,12 & 1,06 & 1,05 & 0,96 & 1,05 \\
\hline $\mathrm{V}$ & 1,10 & 1,08 & 0,96 & 0,93 & 1,02 \\
\hline $\begin{array}{l}\text { Médias de } \\
\text { Tratamentos }\end{array}$ & 1,15 & 1,09 & 1,05 & 0,98 & \\
\hline $\begin{array}{l}\text { Desvio } \\
\text { Padrão }\end{array}$ & 0,05 & 0,03 & 0,08 & 0,06 & \\
\hline
\end{tabular}

Tabela 8. Análise de variância dos dados de Consumo de MS total.

\begin{tabular}{|c|c|c|c|c|c|}
\hline Fontes de Variação & G.L. & SQ & $\mathrm{QM}$ & F & \\
\hline Níveis de Uréia & 3 & 0,07720 & 0,02570 & 9,880 & $\star *$ \\
\hline \multirow[t]{2}{*}{ regressão } & 1 & 0,07673 & 0,07673 & 29,510 & ** \\
\hline & 1 & 0,000045 & 0,000045 & 0,017 & n.s. \\
\hline cúbića & 1 & 0,000361 & 0,000361 & 0,139 & $\mathrm{n} . \mathrm{s}$. \\
\hline Blocos & 4 & 0,02870 & 0,00720 & 2,770 & n.s. \\
\hline Resíduo & 11 & 0,02900 & 0,00260 & & $\cdot$ \\
\hline TOTAL & 19 & 0,1350 & & & \\
\hline
\end{tabular}

n.s. - Não significativo

* - Significativo ao nível de 5\% de probabilidade

** - Significativo ao nível de 1\% de probabilidade

$\mathrm{CV}=4,70 \%$

$$
Y=1,15-0,005 x
$$




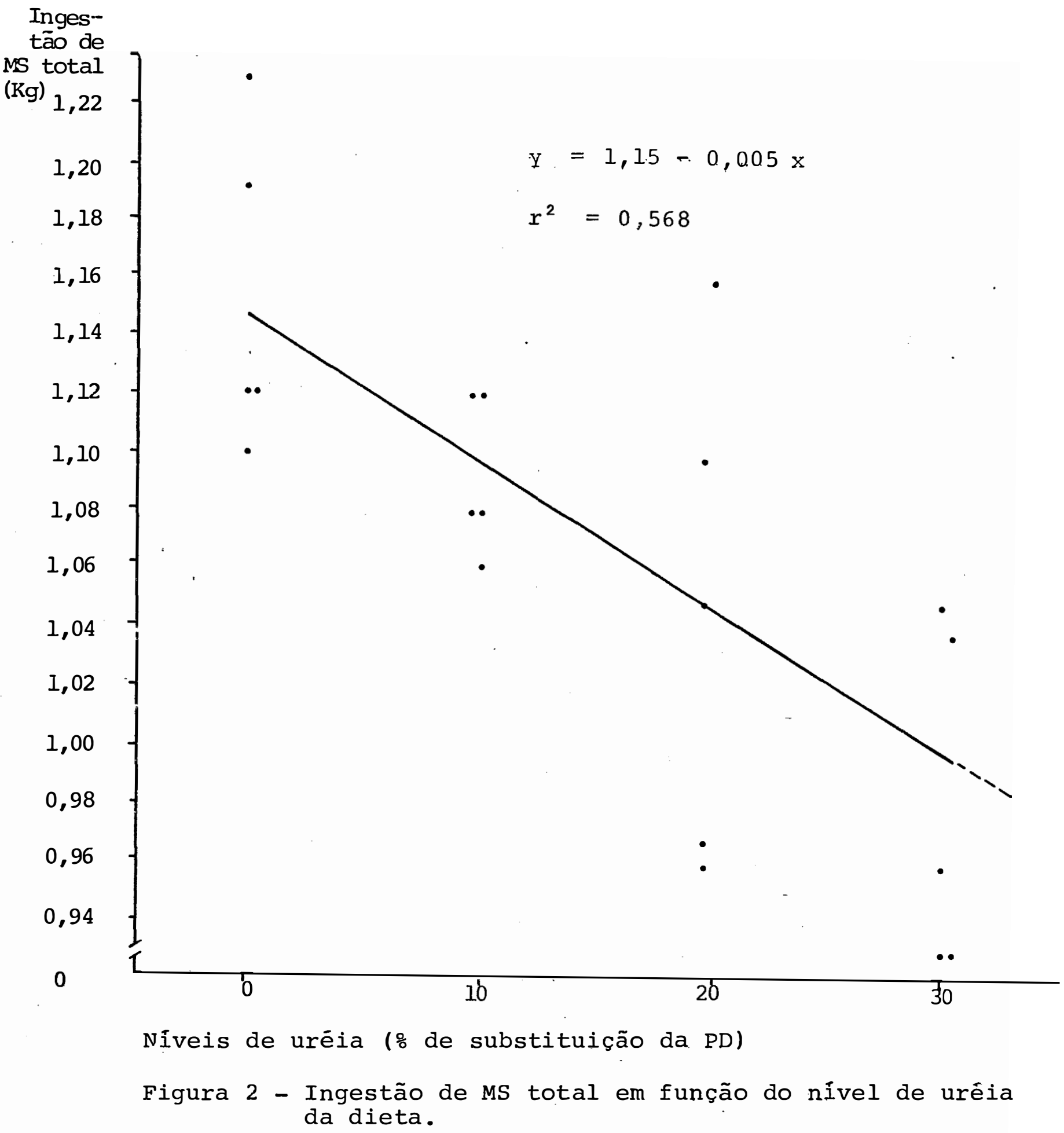


denciado pela análise da variância (Tabela 10) . . Isto parece contrariar as observações de VAN SOEST (1982) e outros autores COmo CHALUPA (1968), VAN .HORN e. MUDD (1971), RINDSIG (1977) e SINGHAL e MUDGAL (1981), sobre o efeito da uréia sobre a ingestão de alimentos. No entanto, o estudo do nível de ingestão de MS de concentrado e de volumoso, em separado, parece evi denciar o efeito negativo da uréia sobre a ingestão de alimentos.

Os níveis de ingestão de MS total por unidade de peso metabólico observados neste trabalho, da ordem de $0,076 \mathrm{~kg}$ de MS por unidade de peso metabólico, são superiores aos citados por KURAR e MUDGAL (1981), que variavam de 0,043 a $0,062 \mathrm{~kg}$ de MS por quilograma de peso metabólico, conforme o nível de energia da dieta de 100 a 130\% da necessidade para manutenção. Também superam o consumo médio diário de $0,040 \mathrm{~kg}$ MS $/ \mathrm{kg} \mathrm{PV}^{0,75}$ observado por GIHAD (1976) em caprinos alimentados com volumoso de baixa qualidade (feno de gramínea com $6,2 \%$ de $\mathrm{PB})$. No entanto, os níveis obtidos neste traba lho podem ser considerados baixos para caprinos de produção elevada, alimentados com forrageiras de valor nutritivo elevado, como os citados por LE JAOUEN (1978), da ordem de $0,126 \mathrm{~kg} \mathrm{MS} / \mathrm{kg} \mathrm{PV}^{0,75}$, em animais com produção anual média de $730 \mathrm{~kg}$ de leite; por SANDS e MCDOWELL (1978), com niveis de ingestão da ordem de 5\% do PV, o que equivale a $0,158 \mathrm{~kg}$ MS $/ \mathrm{kg} \mathrm{PV}^{0,75}$; ou ainda por DEVENDRA (1980), que obteve médias de consumo diário de $0,079,0,088$ e $0,106 \mathrm{~kg}$ MS / $/ \mathrm{kg} \mathrm{PV}{ }^{0,75}$, respectivamente, para raças de caprinos originá- 
Tábela 9. Consumo diărio médio de MS total por $\mathrm{kg} \mathrm{PV}^{0,75}$ (kg)

\begin{tabular}{|c|c|c|c|c|c|}
\hline \multirow{2}{*}{ Blocos } & \multicolumn{4}{|c|}{ Tratamentos } & \multirow{2}{*}{$\begin{array}{c}\text { Média de } \\
\text { blocos }\end{array}$} \\
\hline & A & B & C & D & \\
\hline I & 0,077 & 0,077 & 0,067 & 0,075 & 0,074 \\
\hline II & 0,078 & 0,073 & 0,079 & 0,073 & 0,076 \\
\hline III & 0,076 & 0,071 & 0,085 & 0,072 & 0,076 \\
\hline IV & 0,079 & $0 ; 085$ & 0,081 & 0,080 & 0,081 \\
\hline $\mathrm{V}$ & 0,083 & 0,068 & 0,070 & 0,074 & 0,074 \\
\hline $\begin{array}{l}\text { Médias de } \\
\text { Tratamentos }\end{array}$ & 0,079 & 0,075 & 0,076 & 0,075 & \\
\hline $\begin{array}{l}\text { Desvio } \\
\text { Padrão }\end{array}$ & $0 ; 0027$ & 0,0066 & 0,0076 & 0,0031 & \\
\hline
\end{tabular}

Tabela 10. Análise da variância dos dados de consumo de MS total por $\mathrm{kg}$ de $\mathrm{PV}^{0,75}$

\begin{tabular}{lrccc}
\hline Fontes de Variação & G.L. & SQ & QM & F \\
\hline Níveis de Uréia & 3 & $4,90 \times 10^{-5}$ & $1,63 \times 10^{-5}$ & $0,55 \mathrm{n} . \mathrm{s}$. \\
Blocos & 4 & $1,46 \times 10^{-4}$ & $3,65 \times 10^{-5}$ & $1,23 \mathrm{n} . \mathrm{s}$. \\
Resíduo & $11 \cdot 3,26 \times 10^{-4}$ & $2,96 \times 10^{-5}$ & \\
\hline TOTAL & 19 & $5,21 \times 10^{-4}$ & & \\
\hline
\end{tabular}

n.s. - Não significativo

* - Significativo ao nível de 5\% de probabilidade

** - Significativo ao nível de $1 \%$ de probabilidade

C.V. $=7,14 \%$ 
rias dos trópicos, raças de clima temperado nos trópicos e raças de clima temperado na região de origem.

$$
\text { HUBER e SANDY (1965), VAN HORN e MUDD (1971), }
$$

HUBER (1975) e KERTZ e EVERETT (1975), constataram redução na ingestão de MS quando se substituiu, parcial ou totalmente, fontes de NP por uréia na dieta de bovinos leiteiros. Segundo KERTZ e EVERETT (1975), o efeito negativo da uréia sobre o con sumo acentuou-se ainda mais quando o teor de umidade da dieta aumentou.

RINDSIG (1977) cita que a utilização da uréia em caprinos leiteiros pode ser feita em níveis não superiores a $1 \%$ do total de MS da dieta, sendo que a substituição de NP por NNP não deve ultrapassar a $30 \%$ do total da proteína disponível na dieta, sob risco de redução de consumo. E, segundo CHALUPA (1968), quando a dieta apresenta níveis de $\mathrm{N}$ adequa dos à necessidade animal, a substituição de fontes de NP por uréia pode resultar em diminuição de consumo, seja em razão de problemas de palatabilidade, seja em razão da diminuição do nível de energia, pois o valor energético da uréia é nulo.

Outros trabalhos mostraram aumentos na ingestão de MS quando parte da proteína foi substituída por uréia. SIN GHAL e MUDGAL (1980a) obtiveram, com cabras leiteiras, ingestão diāria de $0,089 \mathrm{~kg}$ MS $/ \mathrm{kg} \mathrm{PV}^{0,75}$ para dieta sem uréia, e de $0,096 \mathrm{~kg} \mathrm{MS} / \mathrm{kg} \mathrm{PV}^{0,75}$ quando a uréia forneceu $50 \%$ do $\mathrm{N}$ da dieta. SINGHAL e MUDGAL (1981), trabalhando com caprinos 
machós adultos, também observaram aumento na ingestão de MS, que passou de $0,067 \mathrm{~kg}$ para $0,071 \mathrm{~kg} \mathrm{MS} / \mathrm{kg} \mathrm{PV}^{0}, 75$, com substituição de $50 \%$ de NP por NNP . Segundo esses autores, $O$ aumento de ingestão de MS pode ser devido ao aumento na velocida de do alimento pelo trato intestinal, e não em razão do aumento da digestibilidade da MS da dieta, que foi menor no trata mento com uréia. No entanto, RAY e PANDEY (1980) não observa ram diferenças significativas na frequência de defecação de animais que tiveram dieta à base de NP ou de NNP e, em virtude da ingestão de MS ter sido semelhante, os autores concluiram que a uréia não influiu sobre a velocidade de trânsito do alimento pelo trato intestinal. SINGHAL (1978) também não observou diferenças na ingestão de MS em cabras leiteiras quan do a uréia forneceu até $50 \%$ do $\mathrm{N}$ da dieta.

Os dados de consumo diário de MS de volumoso por unidade de peso metabólico (Tabela ll) e a correspondente análise da variância (Tabela 12) não evidenciaram diferenças significativas em relação aos diferentes niveis de uréia. 0 mesmo não aconteceu com o consumo de MS de concentrado por uni dade de peso metabólico (Tabela 13), pois os resultados da aná lise da variância (Tabela 14) indicam que os tratamentos diferiram de maneira significativa $(P<0,01)$, tendo havido diminuição de maneira cúbica em relação ao aumento do nível de uréia da dieta. 
Tabela 11. Consumo diārio médio de Volumoso ( $\mathrm{kg}$ MS / $\mathbf{k g}^{\mathrm{p}} \mathrm{PV}^{\mathbf{0}, 75}$ )

\begin{tabular}{|c|c|c|c|c|c|}
\hline \multirow{2}{*}{ Blocos } & \multicolumn{4}{|c|}{ Tratamentos } & \multirow{2}{*}{$\begin{array}{l}\text { Média de } \\
\text { blocos }\end{array}$} \\
\hline & A & B & C & $\mathrm{D}$ & \\
\hline I & 0,057 & 0,060 & 0,050 & 0,061 & 0,057 \\
\hline II & 0,058 & 0,058 & 0,063 & 0,058 & 0,059 \\
\hline III & 0,057 & 0,055 & 0,070 & 0,058 & 0,060 \\
\hline IV & 0,059 & 0,069 & 0,061 & 0,064 & 0,063 \\
\hline $\mathrm{V}$ & 0,062 & 0,052 & 0,055 & 0,059 & 0,057 \\
\hline $\begin{array}{l}\text { Médias dos } \\
\text { Tratamentos }\end{array}$ & 0,059 & 0,059 & 0,060 & 0,060 & \\
\hline $\begin{array}{l}\text { Desvio } \\
\text { Padrão }\end{array}$ & 0,0021 & 0,0064 & 0,0077 & 0,0025 & \\
\hline
\end{tabular}

Tabela 12. Análise da variância dos dados de consumo de Volumoso

\begin{tabular}{lrccc}
\hline Fontes de Variação & G.L. & SQ & QM & F \\
\hline Níveis de Uréia & 3 & $7,40 \times 10^{-6}$ & $2,47 \times 10^{-6}$ & $0,081 \mathrm{n} . \mathrm{s}$. \\
Blocos & 4 & $1,10 \times 10^{-4}$ & $2,75 \times 10^{-5}$ & $0,905 \mathrm{n} . \mathrm{s}$. \\
Resíduo & 11 & $3,34 \times 10^{-4}$ & $3,04 \times 10^{-5}$ & \\
\hline TOTAL & 19 & $4,51 \times 10^{-4}$ & & \\
\hline
\end{tabular}

n.s. - Não significativo

* - Significativo ao nível de 5\% de probabilidade

** - Significativo ao nível de 1\% de probabilidade

C.V. $=9,30 \%$ 
Tabela 1'3. Consumo diārio médio de Concentrado ( $\mathrm{kg}$ MS $/ \mathrm{kg} \mathrm{PV}^{0,75}$ )

\begin{tabular}{|c|c|c|c|c|c|}
\hline \multirow{2}{*}{ Blocos } & \multicolumn{4}{|c|}{ Tratamentos } & \multirow{2}{*}{$\begin{array}{c}\text { Média de } \\
\text { blocos }\end{array}$} \\
\hline & A & B & C & D & \\
\hline I & 0,020 & 0,017 & 0,017 & 0,014 & 0,017 \\
\hline II & 0,020 & 0,015 & 0,016 & 0,015 & 0,016 \\
\hline III & 0,019 & 0,016 & 0,015 & 0,014 & 0,016 \\
\hline IV & 0,020 & 0,016 & 0,020 & 0,016 & 0,018 \\
\hline $\mathrm{V}$ & 0,021 & 0,016 & 0,015 & 0,015 & 0,016 \\
\hline $\begin{array}{l}\text { Médias de } \\
\text { Tratamentos }\end{array}$ & 0,020 & 0,016 & 0,016 & 0,015 & \\
\hline $\begin{array}{l}\text { Desvio } \\
\text { Padrão }\end{array}$ & 0,0007 & 0,0008 & 0,0021 & 0,0008 & \\
\hline
\end{tabular}

Tabela 14. Análise da variância dos dados de consumo de Concentrado.

\begin{tabular}{lccccc}
\hline Fontes de Variação & G:L. & SQ & QM & F \\
\hline Níveis de Uréia & 3 & $7,46 \times 10^{-5}$ & $2,48 \times 10^{-5}$ & $18,02 * *$ \\
regressão linear & 1 & $5,62 \times 10^{-5}$ & $5,62 \times 10^{-5}$ & $40,72 * *$ \\
& quadrática & 1 & $6,05 \times 10^{-6}$ & $6,05 \times 10^{-6}$ & $4,38 \mathrm{n} . \mathrm{s}$. \\
cúbica & 1 & $1,22 \times 10^{-5}$ & $1,22 \times 10^{-5}$ & $8,83 *$ \\
Blocos & 4 & $0,88 \times 10^{-5}$ & $2,21 \times 10^{-6}$ & $1,60 \mathrm{n} . \mathrm{s}$. \\
Resíduo & 11 & $1,52 \times 10^{-5}$ & $1,38 \times 10^{-6}$ & \\
\hline TOTAL & 19 & $9,86 \times 10^{-5}$ & \\
\hline
\end{tabular}

n.s. - Não significativo

* - Significativo ao nível de 5\% de probabilidade

** - Significativo ao nível de $1 \%$ de probabilidade

C. v. $=6,97 \%$

$$
Y=0,02-0,0009 x+0,00006 x^{2}-0,0000012 x^{3}
$$


'A equação de regressão determinada foi:

$$
Y=0,02-0,0009 x+0,00006 x^{2}-0,0000012 x^{3}
$$

A curva referente à equação de regressão pode ser vista na Figura 3.

Nota-se pelos dados de consumo de volumoso e de concentrado que quando se forneceu uréia o consumo de concentrado por kg de peso metabólico diminuiu significativanente $(P<0,01)$, enquanto que o consumo de volumoso apresentou pequena tendência de aumento. Estes dois comportamentos opostos se compensaram, resultando em consumo total de MS, por unidade de peso metabólico, idêntico nos diversos tratamentos.

Considerando-se que as rações de todos os trata mentos foram isoenergéticas e isonitrogenadas, e basicamente compostas pelos mesmos ingredientes, pode-se supor que a presença de uréia, prejudicando a palatabilidade da ração, seja a principal causa do menor consumo de concentrado nos tratamentos B, C. e D.

o consumo de concentrado, em todos os tratamentos, foi inferior ao esperado, e em todos tratamentos os animais eventualmente deixaram sobra. Com isso, a relação entre o consumo de MS de volumoso e MS. de concentrado foi maior que a pré-determinada, passando de $70,3: 29,7$ para $74,7: 25,3$; $78,7: 21,3 ; 79,0: 21,0$ e $80,0: 20,0$, respectivamente, para os tratamentos A, B, C e D. Essas relações são muito su- 


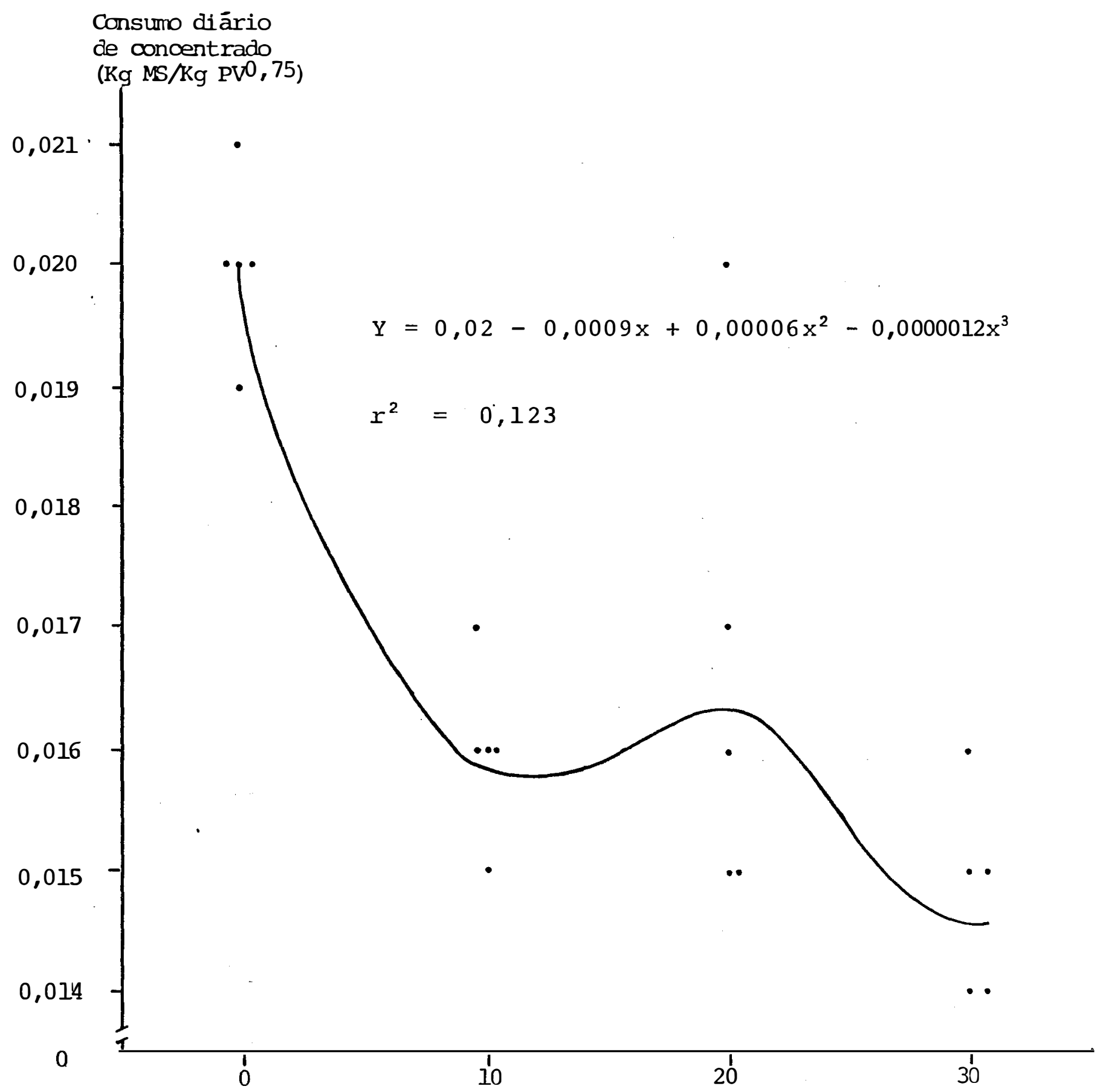

Níveis de uréia (\% de substituição da $\mathrm{PD}$ )

Figura 3 - Ingestão de MS de concentrado por $\mathrm{Kg}$ de $\mathrm{PV}^{0,75} \mathrm{em}$ função do nível de uréia da dieta. 
periores às citadas por MORAND-FERH et alii (1981a), que indicam como ideal a relação de $50: 50$ a $45: 55$ quando a qualí dade do volumoso for baixa, e de $62: 38$ a $60: 40$ quando 0 volumoso for de boa ou média qualidade; sendo esperado, conforme MORAND-FERH e SAUVANT (1978), um consumo médio diārio de 4 \% do PV.

$\bar{E}$ importante observar que apesar da ingestão diāria de 0,075 a $0,079 \mathrm{~kg} \mathrm{MS} / \mathrm{kg} \mathrm{PV}^{0,75}$ ter ficado bem abai xo da média esperada de $0,104 \mathrm{~kg}$, provavelmente em razão da baixa qualidade do volumoso utilizado e da baixa aceitabilidade do concentrado com uréia, o consumo de MS por unidade de pe so metabólico não diferiu entre os tratamentos. Dessa maneira, o fraco desempenho dos animais, de maneira geral, pode ser justificado pela baixa ingestão de MS, enquánto que as diferenças entre os tratamentos parecem ser devioias à variação na qualidade da MS em razão da substituição das fontes de NP por uréia. Essa substituição parece ter afetado a eficiên cia no aproveitamento do alimento ingerido para produção - animal, o que contraria os resultados de SINGHAL e MUDGAL (1980b) para a produção de leite, e de SINGHAL e MUDGAL (1981), para ganho de peso, os quais observaram melhor eficiência no apro veitamento do alimento quando a uréia substituiu parte do fare lo de soja da dieta, seja pelo aumento na digestibilidade do MS, seja pelo aumento na retenção de $\mathbf{N}$, conforme FUJIHARA e TASAKI (1975). Além disso, o desempenho animal pode ter sido afetado pela ingestão 20 a $25 \%$ menor de concentrado nos trata 
- mentos com uréia, acarretando menor ingestão de nutrientes, o que, segundo CHALUPA (1968) e VAN SOEST (1982), resultaria em diminuição da atividade microbiana no rúmen, e consequentemente na ingestão de volumoso.

O consumo diário de MS total, avaliado em porcentagem do PV (Tabela 15), não foi diferente nos vários tratamentos (Tabela 16), confirmando a ausência de efeito da uréia na dieta sobre a ingestão de MS, com base no peso vivo, quando não se diferencia volumoso e concentrado.

O consumo observado, de 3,06 a $3,26 \%$ do PV, ficou abaixo dos valores citados por SANDS e MCDOWELL (1978), de 5\%; por LE JAOUEN (1978), de 4\%, e por HARRIS (1980), de 4 a 7\% do PV, obtidos com volumosos de boa a média qualidade. Outros trabalhos, com volumosos de qualidade variável, mostraram resultados inferiores, como os de CHENOST e BOUSQUET (1974), com valores de 2,5 a $3,1 \%$; de MORAND-FEHR e SAUVANT (1978), de 2,1 a 2,2\%, e de DEVENDRA (1980), com índices de ingestão de MS de $3 \%$ do PV .

Os índices de ingestão de MS total observados neste trabalho, quando considerados em porcentagens do PV, aproximam-se dos dados citados na biliografia, para condições de oferecimento exclusivo de volumosos de baixa ou média qualidade, comuns em regiões de clima tropical, conforme comentam SANDS e MCDOWELL (1978). Tais valores podem ser considerados baixos visto que, com a presença do concentrado na dieta, o con 
Tabela 15. Consumo diário médio de MS total (\% do PV)

\begin{tabular}{|c|c|c|c|c|c|}
\hline \multirow{2}{*}{ Blocos } & \multicolumn{4}{|c|}{ Tratamentos } & \multirow{2}{*}{$\begin{array}{l}\text { Média de } \\
\text { blocos }\end{array}$} \\
\hline & A & B & C & D & \\
\hline I & 3,14 & 3,16 & 2,73 & 3,17 & 3,05 \\
\hline II & 3,11 & 2,92 & 3,27 & 2,93 & 3,06 \\
\hline III & 3,05 & 2,86 & 3,65 & 2,97 & 3,13 \\
\hline IV & 3,50 & 3,66 & 3,43 & 3,23 & 3,46 \\
\hline $\mathrm{V}$ & 3,50 & 2,69 & 2,95 & 3,21 & 3,09 \\
\hline $\begin{array}{l}\text { Médias de } \\
\text { Tratamentos }\end{array}$ & 3,26 & 3,06 & 3,21 & 3,10 & \\
\hline $\begin{array}{l}\text { Desvioo } \\
\text { Padrão }\end{array}$ & 0,22 & 0,38 & 0,37 & 0,14 & \\
\hline
\end{tabular}

Tabela 16. Análise da variância dos dados de consumo de MS total

\begin{tabular}{lrrrc}
\hline Fontes de Variação & G.L. & SQ & QM & F \\
\hline Níveis de Uréia & 3 & 0,128 & 0,043 & 0,51 n.s. \\
Blocos & 4 & 0,460 & 0,115 & 1,36 n.s. \\
Resíduo & il & 0,927 & 0,084 & \\
\hline TOTAL & 19 & 1,515 & & \\
\hline
\end{tabular}

n.s. - Não significativo

* - Significativo ao nível de 5\% de probabilidade

** - Significativo ao nível de $1 \%$ de probabilidade

C.V. $=9,18 \%$ 
sumo de MS total deveria ser superior ao obtido quando se oferece exclusivamente volumoso de baixa a média qualidade.

\subsection{Variação Ponderal}

o caprino, à semelhança de outros animais produ tores de leite, possui acentuada capacidade de acúmulo de reser vas de lipídeos, proteínas e minerais durante a segunda metade da lactação e no período seco. Essas reservas são mobilizadas no início da lactação seguinte quando, segundo MORAND-FEHR e SAUVANT (1978), é nutricionalmente difícil e economi camente inviável satisfazer, através da dieta, os requerimentos para a manutenção e produção de leite, em razão da elevada exigência aliada à baixa ingestão de alimentos, comum nesse período.

O resultado das pesagens realízadas no períođo experimental (Tabela 17) e a variação no peso metabólico (Tabela 18) parecem confirmar essa tendência em alguns dos tratamentos.

Conforme se observa na Figura 4 , os animais do tratamento A (sem uréia) e do tratamento $B$ (baixo nível de uréia) ganharam peso, enquanto que os do tratamento $C$ manti. veram $e$ os do tratamento $D$ perderam peso.

A análise da variância dos dados de variação do peso metabólico (Tabela 19) indicou diferenças altamente signi 
ficativa's $(\mathrm{P}<0,01)$ entre as médias, sendo que o ganho de peso decresceu linearmente em relação ao aumento do nível de uréia na dieta.

A equação de regressão determinada foi:

$$
Y=1,45-0,0668 \mathrm{x}
$$

O grāfico referente à equação de regressão da variação de peso metabólico em relação ao aumento do teor de uréia na dieta è apresentado na Figura 5 .

O efeito negativo da uréia, mais acentuado nós tratamentos com substituição de PD acima de $10 \%$ (equivalente a $0,14 \mathrm{~g}$ de uréia por quilo de PV), contriaria as observações de LAMPILA (1972) e de BHATTACHARYA (1980), que não observaram efeitos negativos no formecimento de uréia sobre o ganho de peso em níveis de 0,45 e $0,50 \mathrm{~g}$ de uréia/kg $\mathrm{PV}$, respectiva mente, para cabritas em crescimento. No entanto, SREEMANNARAYANA e MAHAPATRO (1982) observaram maior tenđência de ganho de peso em caprinos que receberam farelo de soja como fonte de $\mathrm{N}$ do que naqueles aos quais foi fornecida uréia substituindo $35 \%$ da $\mathrm{PB}$ da dieta.

\subsection{Características do Leité}

A variação na quantidade e qualidade dos ingre-dientes da dieta afeta, conforme MORAND-FEHR e SAUVANT (1980) 
Tabela 17. Pesagens e variação do $\mathrm{PV}^{0}, 75$ por tratamento:

\begin{tabular}{|c|c|c|c|c|c|c|c|c|}
\hline Blo & $\begin{array}{l}\text { Trata } \\
\text { mento }\end{array}$ & $\begin{array}{l}\text { No do } \\
\text { animal }\end{array}$ & 1 & 2 & 3 & $\hat{m}$ & $\mathrm{PV}^{0,75}$ & $\Delta \mathrm{PV}^{0,75}$ \\
\hline \multirow{4}{*}{ I } & A & 18 & 33,80 & 36,50 & 37,10 & 35,80 & 14,63 & $+1,45$ \\
\hline & B & 11 & 33,80 & 36,00 & 34,30 & 34,70 & 14,29 & $+0,15$ \\
\hline & C & 14 & 35,00 & 35,70 & 36,50 & 35,73 & 14,62 & $+0,46$ \\
\hline & D & 8 & 33,50 & 32,10 & 32,50 & 32,70 & 13,67 & $-0,31$ \\
\hline \multirow{4}{*}{ II } & A & 2 & 34,70 & 41,00 & 43,00 & 39,57 & 15,77 & $+2,49$ \\
\hline & B & 6 & 36,20 & 38,80 & 39,90 & 38,30 & 15,39 & $+1,11$ \\
\hline & C & 19 & 34,40 & 35,80 & 36,20 & 35,47 & 14,53 & $+0,74$ \\
\hline & D & 9 & 31,50 & 32,00 & 32,10 & 31,87 & 13,41 & $+0,18$ \\
\hline \multirow{4}{*}{ III } & A & 1 & 36,60 & 38,80 & 41,90 & 39,10 & 15,64 & $+1,59$ \\
\hline & B & 5 & 37,00 & 40,00 & 40,60 & 39,20 & 15,66 & $+1,08$ \\
\hline & C & 10 & 31,70 & 29,00 & 29,70 & 30,13 & 12,86 & $-0,64$ \\
\hline & D & 7 & 35,50 & 35,60 & 34,70 & 35,27 & 14,47 & $-0,24$ \\
\hline \multirow{4}{*}{ IV } & A & 20 & 32,20 & 34,10 & 35,90 & 34,07 & 14,10 & $+1,60$ \\
\hline & B & 12 & 29,80 & 29,10 & 28,10 & 29,00 & 12,49 & $-0,55$ \\
\hline & C & 16 & 30,20 & 30,60 & 31,00 & 30,60 & 13,01 & $+0,26$ \\
\hline & D & 3a & 31,20 & 29,80 & 28,00 & 29,67 & 12,71 & $-0,48$ \\
\hline \multirow{4}{*}{ V } & A & 17 & 30,40 & 31,60 & 32,70 & 31,57 & 13,32 & $+0,72$ \\
\hline & B & 4 & 37,00 & 42,00 & 42,00 & 40,33 & 16,00 & $-1,50$ \\
\hline & C & 13 & 32,70 & 32,50 & 32,20 & 32,47 & 13,60 & $-0,15$ \\
\hline & D & 15 & 31,90 & 27,80 & 27,00 & 28,90 & 12,46 & $-1,58$ \\
\hline
\end{tabular}

a/ Parcela perdida cujos dados foram estimados conforme GOMES (1976). 


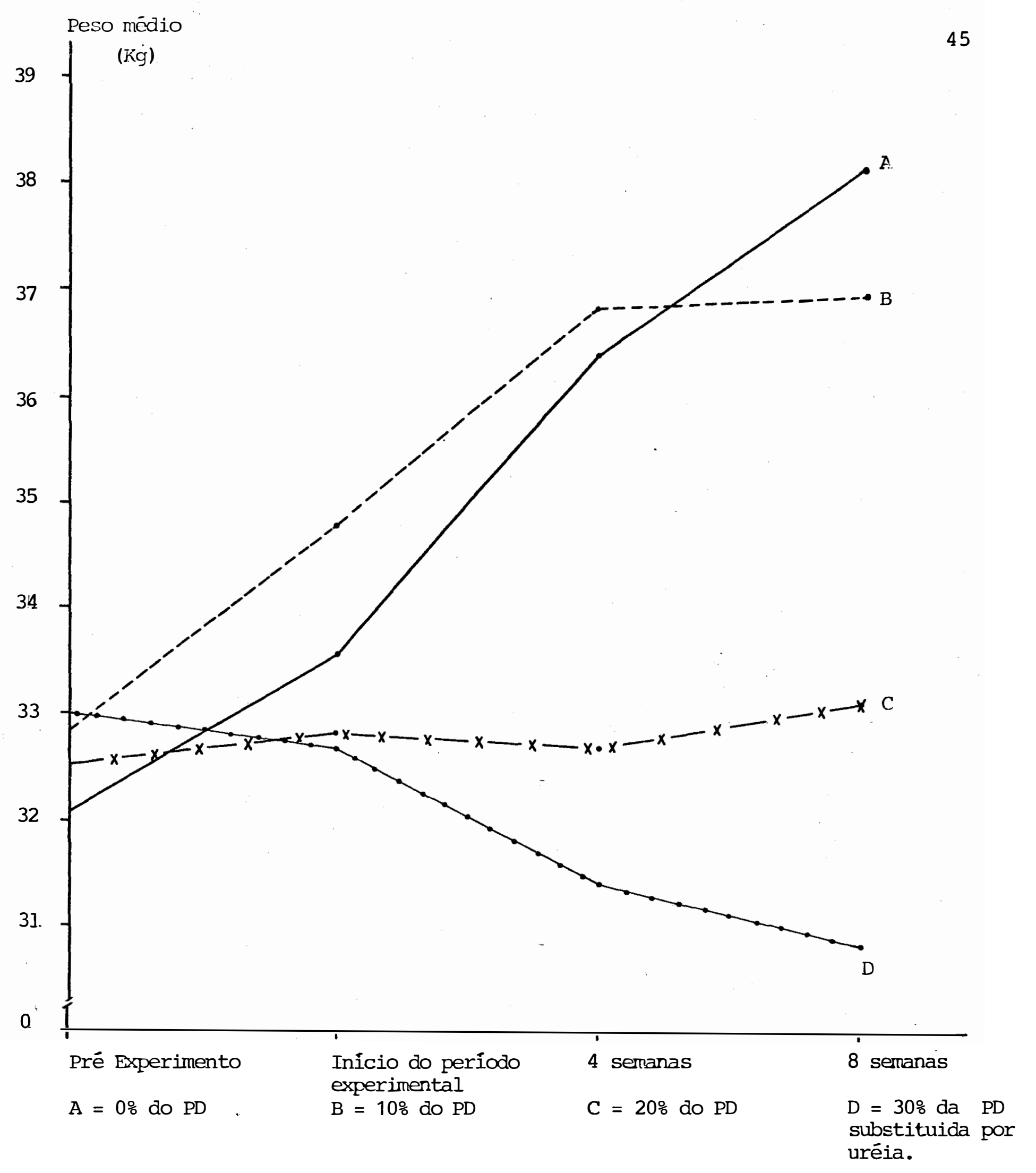

Figura 4 - Variação na média do P.V. por tratamento. 
Tabela 18. Variação no peso metabólico (kg)

\begin{tabular}{|c|c|c|c|c|c|}
\hline \multirow{2}{*}{ Blocos } & \multicolumn{4}{|c|}{ Tratamentos } & \multirow{2}{*}{$\begin{array}{l}\text { Média de } \\
\text { blocos }\end{array}$} \\
\hline & A & B & C & D & \\
\hline I & $+1,42$ & $+0,15$ & $+0,46$ & $-0,31$ & $+0,43$ \\
\hline II & $+2,49$ & $+1,11$ & $+0,74$ & $+0,18$ & $+1,13$ \\
\hline III & $+1,59$ & $+1,08$ & $-0,64$ & $-0,24$ & $+0,45$ \\
\hline IV & $+1,60$ & $-0,55$ & $+0,26$ & $-0,48$ & $+0,21$ \\
\hline $\mathrm{V}$ & $+0,72$ & $+1,50$ & $-0,15$ & $-1,58$ & $+0,12$ \\
\hline $\begin{array}{l}\text { Médias de } \\
\text { Tratamentos }\end{array}$ & $+1,56$ & $+0,66$ & $+0,13$ & $-0,48$ & \\
\hline $\begin{array}{l}\text { Desvio } \\
\text { Padrão }\end{array}$ & 0,63 & 0,84 & 0,54 & 0,66 & \\
\hline
\end{tabular}

Tabela 19. Análise da variância dos dados de variação do $\mathrm{PV}^{0,75}$.

\begin{tabular}{|c|c|c|c|c|}
\hline Fontes de Variação & G.L. & SQ & QM & $\mathrm{F}$ \\
\hline Níveis de Uréia & 3 & 11,290 & 3,763 & $8,63 * *$ \\
\hline \multirow[t]{2}{*}{ regressão } & 1 & 11,130 & 11,130 & $25,53 * *$ \\
\hline & 1 & 0,103 & 0,103 & $0,23 \mathrm{n.s.}$ \\
\hline cúbica & 1 & 0,057 & 0,057 & $0,13 \mathrm{n.s}$. \\
\hline Blocos & 4 & 2,510 & 0,627 & 1,44 n.s. \\
\hline Resíduo & 11 & 4,800 & 0,436 & \\
\hline TOTAL & 19 & 18,60 & & \\
\hline
\end{tabular}

n.s. - Não significativo

* - Significativo ao nível de 5\% de probabilidade

** - Significativo ao nível de $1 \%$ de probabilidade

C.V. $=141,00 \%$

$$
\mathrm{Y}=1,45-0,0668 \mathrm{x}
$$


Variação

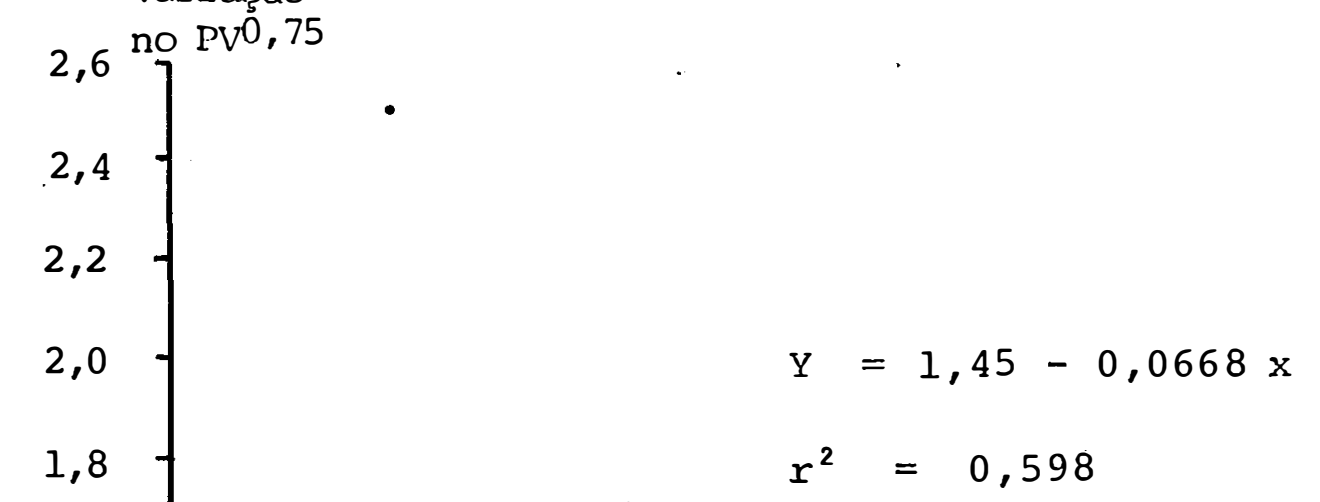

$1,6\}$
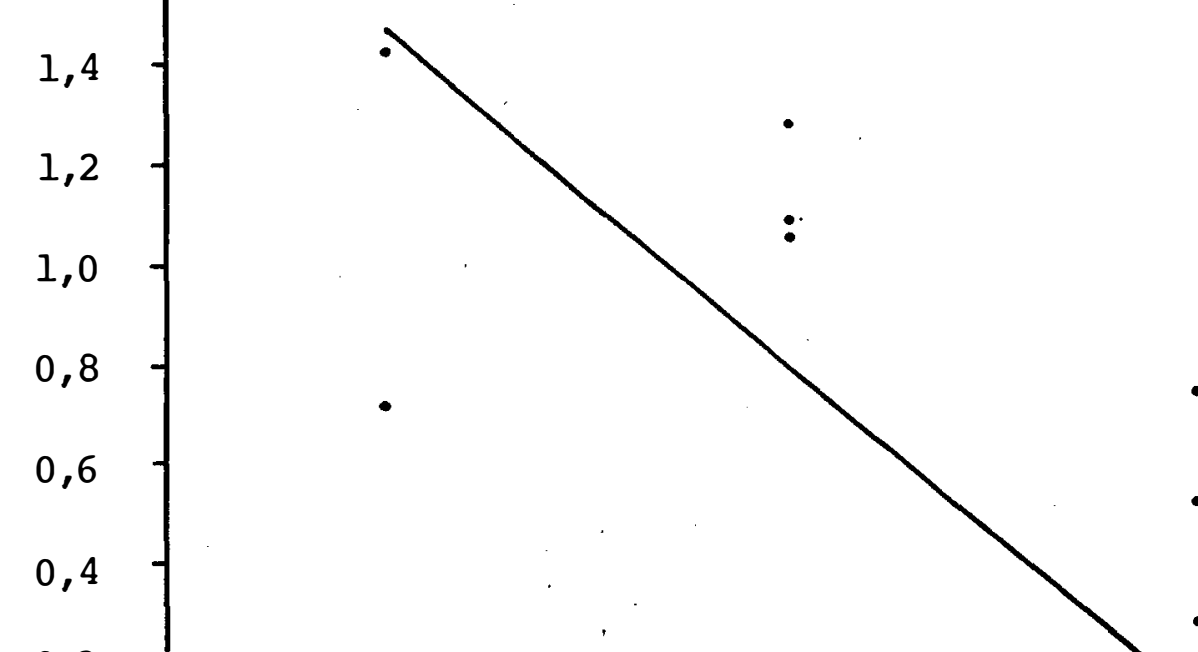

0,2

0

$-0,2$

$-0,4$

$-0,6$

$-0,8$

$-1,0$

$-1,2$

$-1,4$

0

Niveis de uréia (\% de substituição do PD)

Figura 5 - Variação do PV0,75 em função do nível de uréia da dieta. 
e DEVENDRA (1982), as características do leite, principalmente o teor de gordura e de proteína, o que reflete tanto sobre o EST. COMO O ESD.

A observação dos dados correspondentes às três amostragens de cada tratamento, com diferentes níveis de uréia (Tabela 20) e da respectiva análise da variância (Tabela 21), evidenciou diferenças significativas. $(P<0,01)$ entre as médias dos vários níveis de uréia e entre as amostragens.

A aplicação do teste de Tukey mostrou que o teor de gordura foi menor na primeira amostragem que nas últimas, inclusive no tratamento sem uréia, o que parece excluir a ação do NNP nesse aumento, podendo ser ele considerado como resultado da variação normal do teor de gordura do leite duran te o período de lactação, o qual tende a ser alto inicialmente, diminuindo no meio do período e tendendo a aumentar à medida em que se aproxima do final da lactação, conforme constatou DEVENDRA (1972a). MBA et alii (1975) também observaram aumentos no teor de gordura à medida em que se aproximou o final do período de lactação, em caprinos.

o aumento no teor de gordura do leite, em relação ao aumento no nível de uréia, foi significativo $(P<0,01)$ e linear. A equação de regressão determinada foi:

$$
Y=4,27+0,015 x
$$

A curva referente a essa equação de regressão corresponde à Figura 6 . 
Tabela 20. Teor de Gordura do Leite (\%)

\begin{tabular}{|c|c|c|c|c|c|c|c|c|}
\hline \multirow{2}{*}{$\begin{array}{l}\text { Amos } \\
\text { tra- } \\
\text { gem }\end{array}$} & \multirow{2}{*}{$\begin{array}{c}\text { Nível } \\
\text { de } \\
\text { Uréia }\end{array}$} & \multicolumn{5}{|c|}{ B L O C O $\mathrm{S}$} & \multirow{2}{*}{$\begin{array}{c}\text { Média } \\
\text { de } \\
\text { Trat. }\end{array}$} & \multirow{2}{*}{$\begin{array}{l}\text { Desvio } \\
\text { Padrão }\end{array}$} \\
\hline & & $I$ & II & III & IV & $\mathrm{V}$ & & \\
\hline \multirow{4}{*}{ la. } & & 4,1 & 4,1 & 3,9 & 4,0 & 4,3 & 4,08 & 0,15 \\
\hline & $10 \%$ & 4,1 & 4,0 & 4,4 & 3,9 & 4,2 & 4,12 & 0,19 \\
\hline & $20 \%$ & 4,6 & 4,1 & 4,1 & 4,2 & 4,2 & 4,24 & 0,21 \\
\hline & $30 \%$ & 4,0 & 4,2 & 4,2 & 4,1 & 4,2 & 4,14 & 0,09 \\
\hline \multirow{4}{*}{$2 a$. } & $0 \%$ & 4,0 & 4,5 & 4,5 & 4,5 & 4,8 & 4,46 & 0,29 \\
\hline & $10 \%$ & 4,6 & 5,0 & 4,1 & 4,7 & 3,9 & 4,46 & 0,45 \\
\hline & $20 \%$ & 3,9 & 4,9 & 4,8 & 4,4 & 5,0 & 4,60 & 0,45 \\
\hline & $30 \%$ & 4,7 & 4,5 & 5,4 & 5,1 & 5,7 & 5,08 & 0,49 \\
\hline \multirow{4}{*}{$3 a$. } & $0 \%$ & 4,0 & 4,5 & 4,3 & 4,6 & 4,3 & 4,34 & 0,23 \\
\hline & $10 \%$ & 4,5 & 5,0 & 4,3 & 5,1 & 4,1 & 4,60 & 0,43 \\
\hline & $20 \%$ & 4,8 & 4,3 & 4,7 & 5,1 & 5,2 & 4,82 & 0,36 \\
\hline & $30 \%$ & 4,9 & 4,5 & 5,0 & 5,3 & 5,3 & 5,00 & 0,33 \\
\hline
\end{tabular}

Média de blocos

$4,35 \quad 4,47 \quad 4,46 \quad 4,58 \quad 4,60$ 
Tabela 21. Análise da variância dos dados de Gordura.

\begin{tabular}{|c|c|c|c|c|c|}
\hline Fontes de Variação & G.L. & SQ & $\mathrm{QM}$ & F & \\
\hline Níveis de Urēia (N) & 3 & 1,72 & 0,57 & 5,12 & ** \\
\hline \multirow[t]{3}{*}{ regressão linear } & 1 & 1,687 & 1,687 & 15,07 & $* *$ \\
\hline & 1 & 0,028 & 0,028 & 0,25 & n.s. \\
\hline & 1 & 0,0008 & 0,0008 & 0,007 & n.s. \\
\hline Amostragens (A) & 2 & 3,69 & 1,84 & 16,47 & $* *$ \\
\hline Interação $\mathrm{N} \times \mathrm{A}$ & 6 & 0,87 & 0,14 & 1,29 & n.s. \\
\hline Tratamentos & 11 & 6,28 & 0,57 & 5,09 & ** \\
\hline Blocos & 4 & 0,49 & 0,12 & 1,09 & n.s. \\
\hline Resíduo & 43 & 4,80 & 0,112 & & \\
\hline TOTAL & 59 & 11,57 & & & \\
\hline
\end{tabular}

n.s. - Não significativo

* - Significativo ao nível de 5\% de probabilidade

** - Significativo ao nível de $1 \%$ de probabilidade

C.V. $=7,4 \%$

$$
Y=4,27+0,015 x
$$




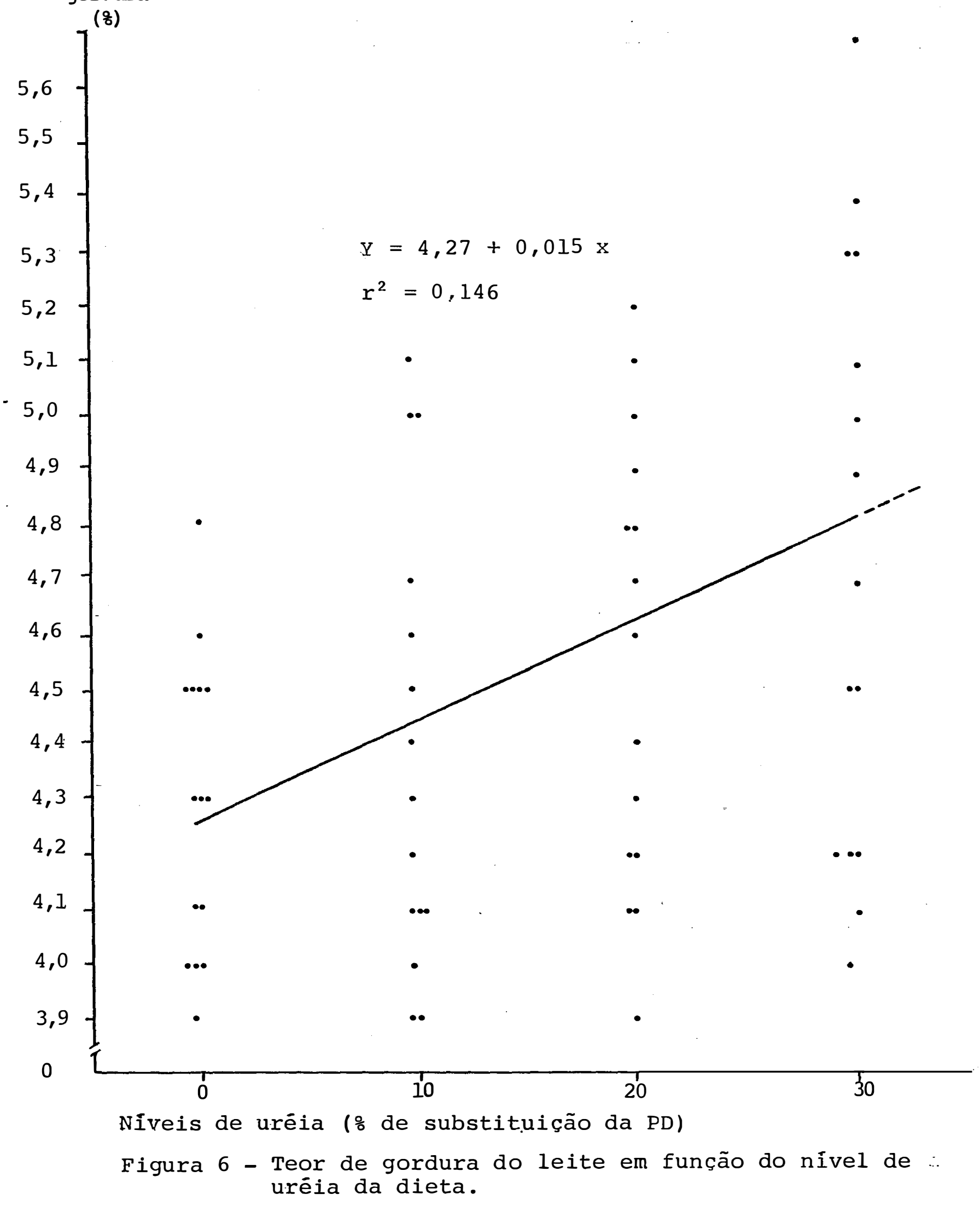


o aumento no teor de gordura do leite quando a uréia substituiu parte do NP da dieta também foi constatado por RYŚ (1967), que observou aumentos de até 50\% no teor de gordura do leite. CONRAD e HIBBS (1968) detectaram leve aumento no teor de gordura do leite de vacas com dietas nas quais 35 a $40 \%$ do $\mathrm{N}$ total era proveniente da uréia. GONZALEZ et alii (1982) verificaram aumentos no teor de gordura do leite de ovelhas que receberam uréia na dieta. VIRTANEN (1967) observou que a variação no teor de gordura do leite passou de 3,8 a $4,8 \%$ para 5,4 a $6,3 \%$ quando todo $\circ \mathrm{N}$ da dieta foi fornecido pela uréia. Neste experimento, só houve resposta ao maior nível de uréia. Entretanto, outros pesquisadores como VAN HORN e JACOBSON (1971), VAN HORN E MUDD(1971), SINGHAL (1978), SAUER et alii (1979), DEVENDRA (1980), e ainda SINGHAL e MUDGAL (1980b), não observaram variações no teor de gordura quando NNP substituiu parcialmente o NP da dieta.

Segundo MORAND - FEHR e SAUVANT (1980) e. DEVEN DRA (1982), a variação no teor de gordura do leite de animais que recebem uréia na dieta pode ser devida a alterações na pro porção molar entre os ácidos graxos voláteis do rúmen-acético, propiônico e butírico- em razão da modificação na digestibilidade da fibra da dieta. Segundo esses mesmos autores, o teor e a digestibilidade dos constituintes fibrosos da dieta teriam influência acentuada sobre o teor de gordura do leite.

DEVENDRA (1982) cita que a redução no consumo 
de MS de volumoso em relação ao consumo de MS de concentrado leva a reduções no teor de gordura do leite. Isso pode justi ficar o aumento no teor de gordura, conforme o observado no presente trabalho, visto que a relação MS do volumoso : MS do concentrado apresentou aumentos de 74,7:25,3\% no ${ }^{-}{ }^{-}$ratamento sem uréia para $80,0: 20,0 \%$ no tratamento com maior nível de uréia.

Quanto ao teor de EST (Tabela 22), não se obse $\underline{\text { }}$ varam diferenças significativas entre as médias (Tabela 23) , seja em razão dos níveis de uréia, seja em razão das amostragens.

Os teores médios observados, de 13,42 a $13,84 \%$, são superiores aos citados por DEVENDRA (1972b), de 11,5 a $12,2 \%$, com raças caprinas de elevada produção. Também superam o valor citado por MBA et alii (1975), para caprinos da raça Saanen, de $12,15 \%$, mas ficam abaixo dos valores citados para as raças nativas das regiões tropicais (Red Sokoto e African Dwarf), de 15,28 e 17,87\% respectivamente. São também inferiores ao valor observado por AKINSOYINU et alii (1977), de $18,68 \%$ na raça African Dwarf.

A constância no teor de EST em relação ao'nível de uréia está em concordância com as observações de VAN HORN e JACOBSON (1971), VAN HORN e MUDD (1971) e DEVENDRA (1980), com bovinos; de GONZALEZ et a $z_{i} i$ (1982), com ovinos, e ainda de SINGHAL e MUDGAL (1980b), que observaram em caprinos valores de 13,12 e 13,67\% para dietas com e sem uréia respectivamente. Resultado semelhante foi obtido por SINGHAL (1978). No 
Tabela 22. Teor de Extrato Seco Total do Leite (\%)

\begin{tabular}{|c|c|c|c|c|c|c|c|c|}
\hline \multirow{2}{*}{$\begin{array}{c}\text { Amos } \\
\text { tra- } \\
\text { gem }\end{array}$} & \multirow{2}{*}{$\begin{array}{c}\text { Nível } \\
\text { de } \\
\text { Uréia }\end{array}$} & \multicolumn{5}{|c|}{$B L O C O S$} & \multirow{2}{*}{$\begin{array}{c}\text { Média } \\
\text { de } \\
\text { Trat. }\end{array}$} & \multirow{2}{*}{$\begin{array}{l}\text { Desvio } \\
\text { Padrão }\end{array}$} \\
\hline & & I & II & III & IV & $\mathrm{V}$ & & \\
\hline \multirow{4}{*}{ la. } & $0 \%$ & 12,71 & 13,25 & 13,48 & 13,56 & 14,56 & 13,51 & 0,67 \\
\hline & $10 \%$ & 13,43 & 14,01 & 13,47 & 12,99 & 13,58 & 13,50 & 0,36 \\
\hline & $20 \%$ & 14,48 & 12,68 & 13,97 & 13,31 & 13,12 & 13,51 & 0,71 \\
\hline & $30 \%$ & 12,30 & 13,56 & 14,29 & 13,57 & 13,40 & 13,42 & 0,72 \\
\hline \multirow{4}{*}{$2 a$. } & $0 \%$ & 12,97 & 13,57 & 13,38 & 13,38 & 14,46 & 13,55 & 0,55 \\
\hline & $10 \%$ & 13,63 & 13,87 & 13,36 & 13,01 & 13,28 & 13,43 & 0,33 \\
\hline & $20 \%$ & 13,23 & 12,88 & 13,57 & 14,17 & 13,37 & 13,44 & 0,48 \\
\hline & $30 \%$ & 12,71 & 13,66 & 14,46 & 13,89 & 14,50 & 13,84 & 0,73 \\
\hline \multirow{4}{*}{$3 a}$. & $0 \%$ & 12,85 & 13,52 & 13,40 & 13,30 & 14,50 & 13,51 & 0,61 \\
\hline & $10 \%$ & 13,53 & 13,97 & 13,35 & 13,40 & 13,43 & 13,54 & 0,25 \\
\hline & $20 \%$ & 13,20 & 12,78 & 13,70 & 13,90 & 14,00 & 13,52 & 0,51 \\
\hline & $30 \%$ & 12,91 & 13,60 & 14,31 & 13,77 & 14,45 & 13,81 & 0,62 \\
\hline
\end{tabular}

Média de $13,16 \quad 13,46 \quad 13,73 \quad 13,52 \quad 13,88$ blocos 
Tabela 23. Análise da variância dos dados de Extrato Seco Total do Leite

\begin{tabular}{|c|c|c|c|c|}
\hline Fontes de Variação & G.L. & SQ & QM & $\mathbf{F}$ \\
\hline Níveis de Uréia (N) & 3 & 0,12 & 0,04 & $0,148 \mathrm{n} . \mathrm{s}$. \\
\hline Amostragens (A) & 2 & 0,41 & 0,20 & 0,740 n.s. \\
\hline Interação $\mathrm{N} \times \mathrm{A}$ & 6 & 0,48 & 0,08 & $0,296 \mathrm{n} . \mathrm{s}$. \\
\hline Tratamentos & 11 & 1,01 & 0,09 & $0,333 \mathrm{n} . \mathrm{s}$. \\
\hline Blocos & 4 & 3,68 & 0,92 & $3,407 *$ \\
\hline Resíduo & 43 & 11,76 & 0,27 & \\
\hline TOTAL & 59 & 16,45 & . & \\
\hline
\end{tabular}

n.s. - Não significativo

* - Significativo ao nível de 5\% de probabilidade

** - Significativo ao nível de $1 \%$ de probabilidade

C.V. $=3,83 \%$ 
entanto, VIRTANEN (1967) registrou aumentos no teor de EST .

O teor de ESD, assim como o EST, não variou em função do teor de uréia na dieta. Contudo, foram observadas diferenças entre as amostragens. Os dados de ESD observados (Tabela 24) e o resultado da análise da variância (Tabela 25) indicam diferenças significativas $(P<0,01)$, sendo que a aplicação do Teste de Tukey mostrou que a média da primeira amostragem foi superior às demais . No entanto, a significân cia estatística das diferenças ficou evidenciada somente nos tratamentos com uréia.

A observação dos dados leva a supor que essa variação no ESD esteja relacionada à variação normal na composição do leite com o transcorrer da lactação, visto que também no tratamento sem uréia observou-se uma tendência de diminuição, apesar da não significância das diferenças entre as mêdias das amostragens.

O ESD é composto pela lactose e principalmente pela matéria nitrogenada do leite cujo teor, conforme MORAND-FEHR e SAUVANT (1981b), varia durante o período de lactação, diminuindo gradativamente do início até o meio do período, para então voltar a aumentar até o final da lactação. Isto explica a variação no teor de ESD observada neste trabalho, visto que o período experimental coincidiu com o período de declí nio do teor da matéria nitrogenada do leite. No entanto, DEVENDRA (1972a) e MBA et alii (1975) não observaram variação 
Tabela 24. Teor de Extrato Seco Desengordurado do Leite (\%)

\begin{tabular}{|c|c|c|c|c|c|c|c|c|}
\hline \multirow{2}{*}{$\begin{array}{l}\text { Amos } \\
\text { tra- } \\
\text { gem }\end{array}$} & \multirow{2}{*}{$\begin{array}{c}\text { Nível } \\
\text { de } \\
\text { Uréia }\end{array}$} & \multicolumn{5}{|c|}{$\mathrm{B} \mathrm{L} O \mathrm{CO} \mathrm{S}$} & \multirow{2}{*}{$\begin{array}{c}\text { Media } \\
\text { de } \\
\text { Trat. }\end{array}$} & \multirow{2}{*}{$\begin{array}{l}\text { Desvio } \\
\text { Padrão }\end{array}$} \\
\hline & & $I$ & II & III & IV & $\mathrm{V}$ & & \\
\hline \multirow{4}{*}{ la. } & $0 \%$ & 8,61 & 9,15 & 9,58 & 9,56 & 10,29 & 9,44 & 0,62 \\
\hline & $10 \%$ & 9,33 & 10,01 & 9,07 & 9,09 & 9,38 & 9,38 & 0,38 \\
\hline & $20 \%$ & 9,88 & 8,58 & 9,87 & 9,11 & 8,92 & 9,27 & 0,58 \\
\hline & $30 \%$ & 8,30 & 9,36 & 10,09 & 9,47 & 9,20 & 9,28 & 0,64 \\
\hline \multirow{4}{*}{$2 a$. } & $0 \%$ & 8,97 & 9,07 & 8,88 & 8,88 & 9,66 & 9,09 & 0,33 \\
\hline & $10 \%$ & 9,03 & 8,87 & 9,26 & 8,31 & 9,38 & 8,97 & 0,42 \\
\hline & $20 \%$ & 8,33 & 8,98 & 8,77 & 8,97 & 9,17 & 8,84 & 0,32 \\
\hline & $30 \%$ & 9,01 & 9,16 & 9,36 & 8,92 & 9,40 & 9,17 & 0,21 \\
\hline \multirow{4}{*}{$3 a}$. & $0 \%$ & 8,85 & 9,02 & 9,10 & 8,70 & 10,20 & 9,17 & 0,59 \\
\hline & $10 \%$ & 9,03 & 8,97 & 9,05 & 8,30 & 9,33 & 8,94 & 0,38 \\
\hline & $20 \%$ & 8,40 & 8,48 & 9,00 & 8,80 & 8,80 & 8,69 & 0,25 \\
\hline & $30 \%$ & 8,01 & 9,10 & 9,31 & 8,47 & 9,15 & 8,81 & 0,55 \\
\hline
\end{tabular}

Média de blocos

$$
8,81 \quad 9,06 \quad 9,29 \quad 8,88 \quad 9,41
$$


Tabela 25. Análise da variância dos dados de Extrato Seco Desengordurado

\begin{tabular}{|c|c|c|c|c|}
\hline Fontes de Variação & G.L. & SQ & QM & $\mathbf{F}$ \\
\hline Nível de Uréia (N) & 3 & 0,66 & 0,220 & 1,31 n.s. \\
\hline Amostragens (A) & 2 & 2,07 & 1,035 & $6,16 * *$ \\
\hline Interação $\mathrm{N}$ x A & 6 & 0,37 & 0,062 & 0,37 n.s. \\
\hline Tratamentos & 11 & 3,10 & 0,282 & 1,67 n.s. \\
\hline & & - & & \\
\hline Blocos & 4 & 3,08 & 0,770 & $4,58 \mathrm{n} . \mathrm{s}$. \\
\hline Resíduo & 43 & 7,22 & 0,168 & \\
\hline TOTAL & 59 & 13,40 & & \\
\hline
\end{tabular}

n.s. - Não significativo

* - Significativo ao nível de 5\% de probabilidade

** - Significativo ao nível de 1\% de probabilidade

C.V. $=4,51 \%$ 
significativa no teor de ESD durante o período de lactação de caprinos .

A maior intensidade de variação, do teor de $E_{\text {a }}$ entre as amostragens dos tratamentos com uréia que do tratamento sem uréia, pode ser explicada pela tendência de aumento no teor de NNP do leite quando a dieta apresenta fontes de NNP ou fontes de NP de fácil degradação no rúmen, conforme citam MORAND - FEHR et alii (1981b).

Os dados observados neste trabalho. concorcam com as observações de VAN HORN e JACOBSON (1971), SINGHAL (1978), SAUER et alii (1979), DEVENDRA (1980) e SINGHAL e MUDGAL (1980b), os quais não observaram variações no teor de ESD em função do nível de uréia. Por outro lado, VIRTANEN (1967) cị ta aumentos no teor de ESD no leite de animais que receberam uréia na dieta, em razão do aumento no teor de proteína do leite.

De maneira geral, os teores de ESD obtidos neste trabalho, de 8,69 a 9,44\%, aproximam-se bastante dos valo res médios citados por SIRRY e HASSAN (1954), de 8,56\% ; MBA et alii (1975), de 8,24 a 11,95\% e SINGHAL e MUDGAL $(1980 \mathrm{~b})$, de $8,09 \%$.

Os dados sobre a densidade do leite (Tabela 26) e a correspondente análise da variância (Tabela 27), ao contrạ rio do ESD, não mostraram diferenças em função das amostragens, mas variaram linear e significativamente $(P<0,01)$ em função direta dos níveis de uréia. 
Tabela 26. Densidade do Leite (g/l)

\begin{tabular}{|c|c|c|c|c|c|c|c|c|}
\hline \multirow{2}{*}{$\begin{array}{c}\text { Amos } \\
\text { tra- } \\
\text { gem }\end{array}$} & \multirow{2}{*}{$\begin{array}{c}\text { Nível } \\
\text { de } \\
\text { Uréia }\end{array}$} & \multicolumn{2}{|r|}{ B } & 0 & \multicolumn{2}{|l|}{ כ $s$} & \multirow{2}{*}{$\begin{array}{c}\text { Média } \\
\text { de } \\
\text { Trat. }\end{array}$} & \multirow{2}{*}{$\begin{array}{l}\text { Desvio } \\
\text { Padrão }\end{array}$} \\
\hline & & $I$ & II & III & IV & $\mathrm{V}$ & & \\
\hline \multirow{4}{*}{ la. } & $0 \%$ & 1031,2 & 1030,8 & 1031,1 & 1031,2 & 1031,2 & 1031,1 & 0,17 \\
\hline & $10 \%$ & 1031,4 & 1031,3 & 1031,7 & 1031,6 & 1031,6 & 1031,5 & 0,16 \\
\hline & $20 \%$ & 1031,9 & 1031,3 & 1032,2 & 1032,2 & 1031,3 & 1031,8 & 0,45 \\
\hline & $30 \%$ & 1031,9 & 1032,0 & 1032,2 & 1032,3 & 1032,1 & 1032,1 & 0,16 \\
\hline \multirow{4}{*}{$2 a$. } & $0 \%$ & 1031,6 & 1031,6 & 1030,9 & 1030,9 & 1031,3 & 1031,3 & 0,35 \\
\hline & $10 \%$ & 1031,4 & 1030,4 & 1032,7 & 1031,2 & 1033,0 & 1031,7 & 1,08 \\
\hline & $20 \%$ & 1031,4 & 1031,6 & 1032,9 & 1031,8 & 1031,6 & 1031,9 & 0,60 \\
\hline & $30 \%$ & 1032,0 & 1032,0 & 1032,3 & 1031,7 & 1032,5 & 1032,1 & 0,31 \\
\hline \multirow{4}{*}{$3 a}$. & $0 \%$ & 1031,3 & 1031,3 & 1031,4 & 1030,9 & 1031,4 & 1031,3 & 0,21 \\
\hline & $10 \%$ & 1031,5 & 1031,4 & 1032,1 & 1031,3 & 1031,9 & 1031,6 & 0,34 \\
\hline & $20 \%$ & 1031,0 & 1031,6 & 1032,4 & 1031,9 & 1031,6 & 1031,7 & 0,51 \\
\hline & $30 \%$ & 1031,8 & 1031,7 & 1032,6 & 1031,8 & 1031,9 & 1031,9 & 0,36 \\
\hline
\end{tabular}

Média de 1031,5 1031,42 1032,04 1031,57 1031,78 blocos 
Tabela 27. Análise da variância dos dados de Densidade.

\begin{tabular}{|c|c|c|c|c|c|}
\hline Fontes de Variação & G.L. & sQ & QM & F & \\
\hline Niveis de Uréia (N) & 3 & 5,61 & 1,870 & 12,90 & ** \\
\hline \multirow[t]{3}{*}{ regressão linear } & 1 & 5,41 & 5,410 & 37,36 & ** \\
\hline & 1 & 0,09 & 0,090 & 0,62 & n.s. \\
\hline & 1 & 0,11 & 0,110 & 0,76 & n.s. \\
\hline Amostragens (A) & 2 & 0,15 & $0,0.75$ & 0,52 & n.s. \\
\hline Interação $\mathrm{N} \times \mathrm{A}$ & 6 & 0,10 & 0,017 & 0,12 & n.s. \\
\hline Tratamentos & 11 & 5,86 & 0,533 & 3,67 & ** \\
\hline Blocos & 4 & 2,91 & 0,727 & 5,02 & * \\
\hline Resíduo & 43 & 6,23 & 0,145 & & \\
\hline TOTAL & 59 & 15,00 & & & \\
\hline
\end{tabular}

n.s. - Não significativo

* - Significativo ao nível de 5\% de probabilidade

** - Significativo ao nível de $1 \%$ de probabilidade

C. V. $=0,04 \%$

$$
Y=1031,27+0,0269 x
$$


A equação de regressão determinada foi:

$$
\mathrm{Y}=1031,27+0,0269 \mathrm{x}
$$

A curva referente à equação de regressão da den sidade em relação aos níveis de uréia encontra-se na Figura 7.

VIRTANEN (1967) relaciona o aumento no teor de proteína do leite com o aumento do nível de uréia na dieta, sen do que esse aumento poderia ser a causa do aumento da densidade.

Os níveis de densidade observados, de 1031,1 a $1032,1 \mathrm{~g} / 1$, são semelhantes aos observados por MELLO e ROGICK (1941) em caprinos com dieta sem uréia de 1031,32 g/l.

Os dados relativos ao índice de acidez. (Tabela 28) e a respectiva análise da variância (Tabela 29) não mos traram diferenças significativas entre as médias, seja em razão das amostragens, seja dos níveis de uréia. Esse resultado contraria os mencionados por RYŚ (1967), onde ocorreram au mentos na acidez em correspondência ao aumento do nível de uréia na dieta de bovinos. Contudo, os índices obtidos aproximam-se dos citados por MELLO e ROGICK (1941) para caprinos com dietas isentas de uréia, de $14,78^{\circ} \mathrm{D}$.

As médias, por tratamento, dos dados de produção de leite, ingestão de M.S. por animal, ingestão de M.S. to tal, M.S. de volumoso e M.S. de concentrado por unidade de peso metabólico, ingestão de M.S. em porcentagem do P.V., bem 
Tabela 28. Índice de Acidez do Leite ( ${ }^{\circ}$ Dornic)

\begin{tabular}{|c|c|c|c|c|c|c|c|c|}
\hline \multirow{2}{*}{$\begin{array}{c}\text { Amos } \\
\text { tra } \\
\text { gem }\end{array}$} & \multirow{2}{*}{$\begin{array}{c}\text { Nível } \\
\text { de } \\
\text { Uréia }\end{array}$} & \multicolumn{5}{|c|}{$B$ L O COS } & \multirow{2}{*}{$\begin{array}{c}\text { Média } \\
\text { de } \\
\text { Trat. }\end{array}$} & \multirow{2}{*}{$\begin{array}{l}\text { Desvio } \\
\text { Padrão }\end{array}$} \\
\hline & & I & II & III & IV & $\mathrm{v}$ & & \\
\hline \multirow{4}{*}{ la. } & $0 \%$ & 16,0 & 16,5 & 16,5 & 17,0 & 16,0 & 16,4 & 0,42 \\
\hline & $10 \%$ & 16,5 & 16,0 & 16,0 & 16,5 & 16,5 & 16,3 & 0,27 \\
\hline & $20 \%$ & 16,5 & 17,0 & 16,5 & 17,5 & 16,5 & 16,8 & 0,44 \\
\hline & $30 \%$ & 16,0 & 16,5 & 17,0 & 16,0 & 17,0 & 16,5 & 0,50 \\
\hline \multirow{4}{*}{$2 a$. } & $0 \%$ & 16,5 & 16,0 & 16,5 & 16,5 & 17,0 & 16,5 & 0,35 \\
\hline & $10 \%$ & 17,0 & 16,5 & 16,5 & 16,0 & 16,0 & 16,4 & 0,42 \\
\hline & $20 \%$ & 17,5 & 17,0 & 16,0 & 16,5 & 16,0 & 16,6 & 0,65 \\
\hline & $30 \%$ & 16,0 & 16,0 & 16,5 & 17,0 & 16,5 & 16,4 & 0,42 \\
\hline \multirow{4}{*}{$3 a$. } & $0 \%$ & 16,0 & 17,0 & 16,5 & 16,0 & 17,5 & 16,6 & 0,65 \\
\hline & $10 \%$ & 16,5 & 16,5 & 17,0 & 16,0 & 16,5 & 16,5 & 0,35 \\
\hline & $20 \%$ & 17,5 & 16,0 & 16,5 & 17,0 & 16,0 & 16,6 & 0,65 \\
\hline & $30 \%$ & 16,5 & 16,5 & 16,0 & 16,3 & 17,0 & 16,5 & 0,36 \\
\hline
\end{tabular}

Média de blocos $16,54 \quad 16,46 \quad 16,46 \quad 16,53 \quad 16,54$ 
Tabela 29. Análise da variância dos dados de Acidez.

\begin{tabular}{|c|c|c|c|c|}
\hline Fontes de Variação & G.L. & SQ & QM & $\mathbf{F}$ \\
\hline Níveis de Uréia (N) & 3 & 0,60 & 0,200 & 0,80 n.s. \\
\hline Amostragens (A) & 2 & 0,04 & 0,020 & $0,08 \mathrm{n} . \mathrm{s}$. \\
\hline Interação $\mathrm{N} \times \mathrm{A}$ & 6 & 0,32 & 0,053 & $0,21 \mathrm{n} . \mathrm{s}$. \\
\hline Tratamentos & 11 & 0,96 & 0,087 & $0,34 \mathrm{n} . \mathrm{s}$. \\
\hline Blocos & 4 & 0,09 & 0,022 & 0,088 \\
\hline Resíduo & 43 & 10,74 & 0,249 & \\
\hline TOTAL & 59 & 11,79 & & \\
\hline
\end{tabular}

n.s. - Não significativo

* - Significativo ao nível de 5\% de probabilidade

** - Significativo ao nível de 1\% de probabilidade

C.V. $=3,03 \%$ 


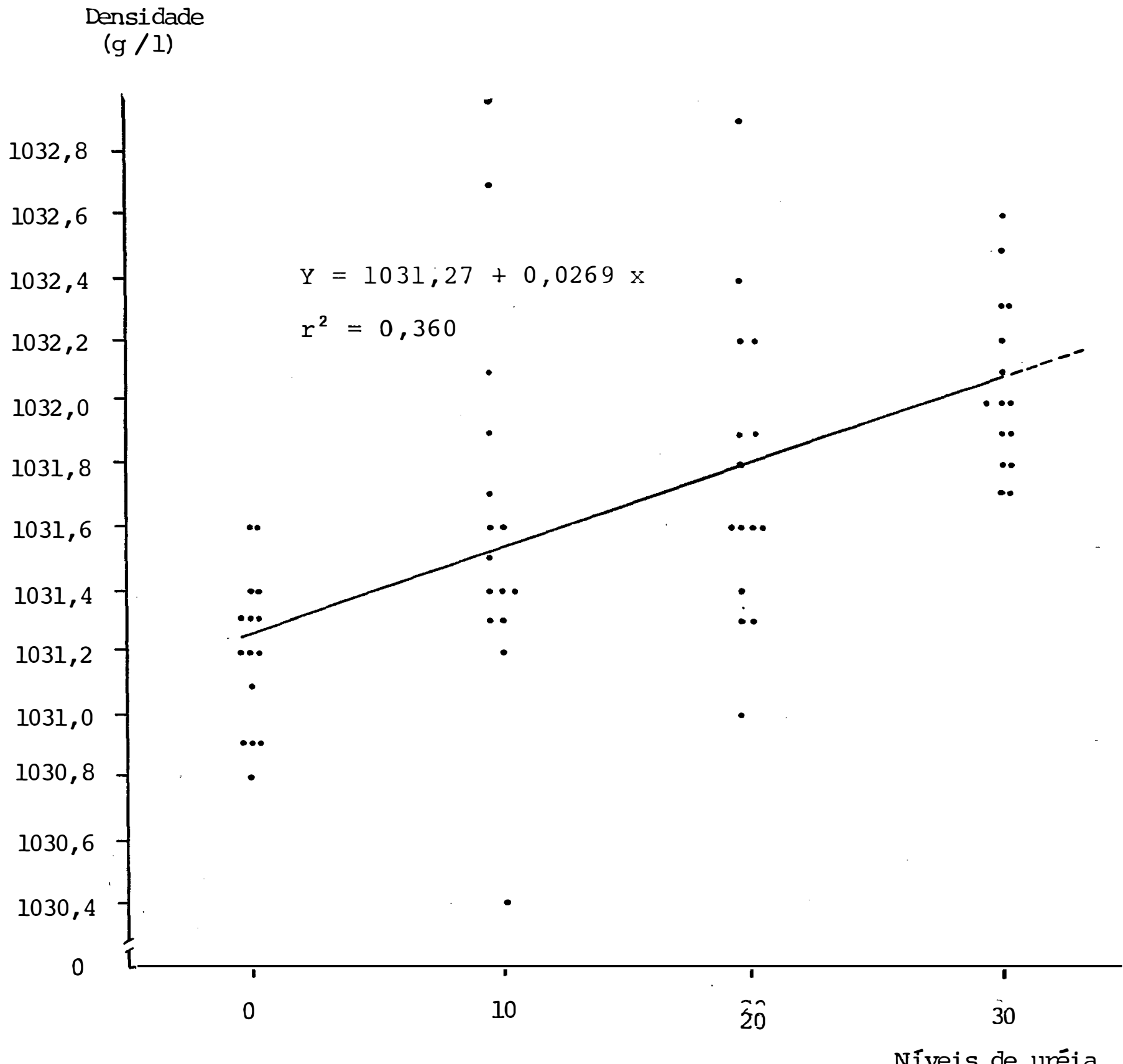

(\% de substituição da PD)

Figura 7. Densidade do leite em função do nível de uréia da dieta. 
como a variação ponderal no períođà experimental encontram-se na Tabela 30 , enquanto que as médias gerais para os parâme tros qualitativos do leite são apresentados na Tabela 31. 
Tabela 30. Médias de produção de leite, consumo diário de 'MŚ e variação ponderal, por tratamento.

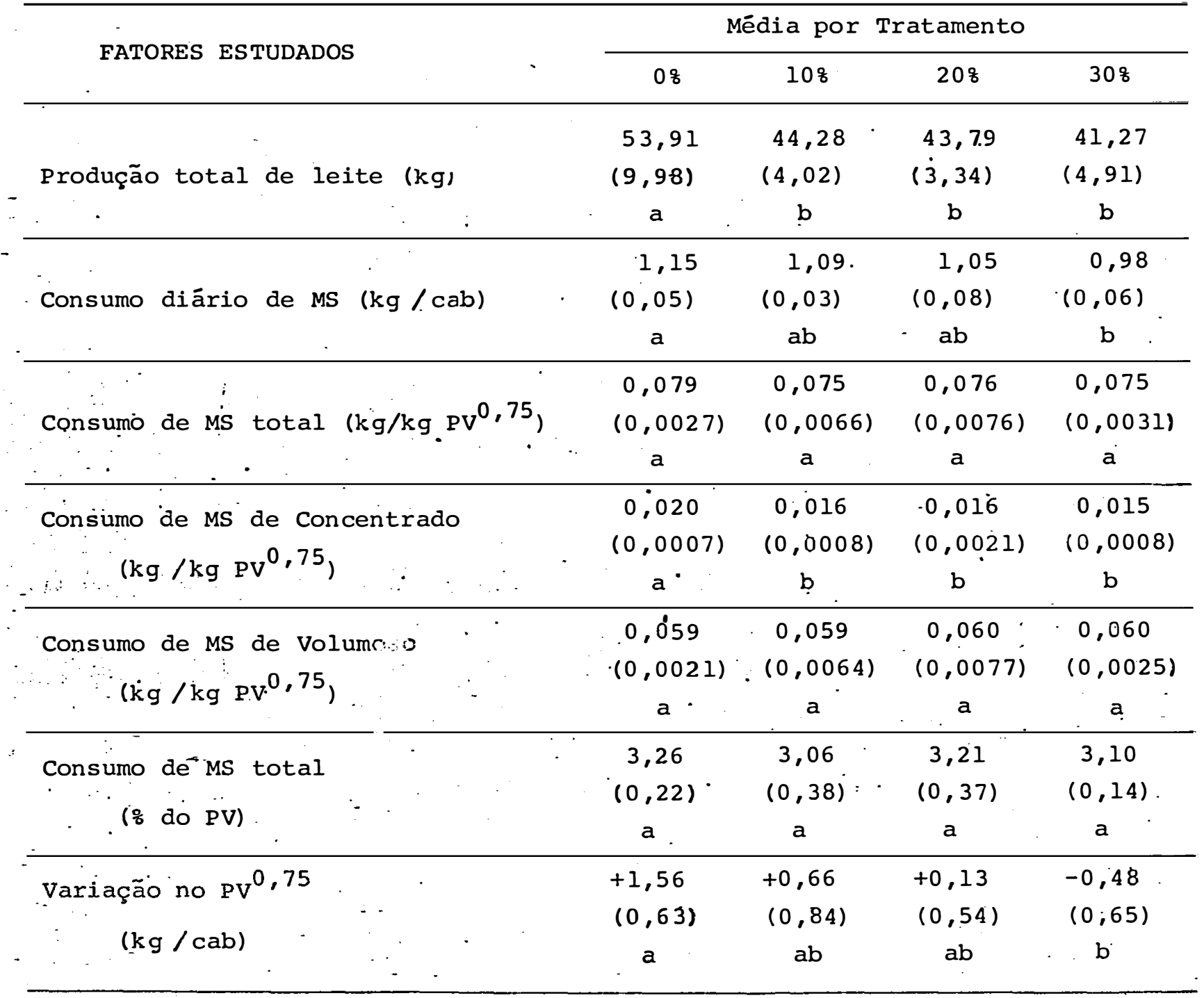

If Os valores entre parêntesis correspondem ao desvio padrão.

2f As médias com a mesma letra näo diferem estatisticamente entre si. 
Tabela 31 - Média das características do leite por tratamento

\begin{tabular}{|c|c|c|c|c|c|}
\hline \multirow{2}{*}{$\begin{array}{c}\text { Fatores } \\
\text { Estudados }\end{array}$} & \multirow{2}{*}{$\begin{array}{l}\text { Amos } \\
\text { tra- } \\
\text { gem }\end{array}$} & \multicolumn{4}{|c|}{ Média por Tratamento } \\
\hline & & 08 & 100 & 208 & 308 \\
\hline \multirow{3}{*}{$\begin{array}{c}\text { GORDURA } \\
\text { (8) }\end{array}$} & 1 & $\begin{array}{c}4,08 \mathrm{Aa}^{\mathrm{i}} \\
(0,15)^{-1}\end{array}$ & $\begin{array}{c}4.12 \\
(0,19)^{\mathrm{Aa}}\end{array}$ & $\begin{array}{c}4.24 \\
(0,21)^{\mathrm{Aa}}\end{array}$ & $\begin{array}{l}4,14 \\
(0,09)\end{array}$ \\
\hline & 2 & $\begin{array}{c}4.46 \\
(0,29)^{\mathrm{Ba}}\end{array}$ & $\begin{array}{c}4,46 \\
(0,45)^{B a}\end{array}$ & $\begin{array}{c}4,60 \\
(0,45)\end{array}$ & $\begin{array}{c}5,08 \\
(0,49)\end{array}$ \\
\hline & 3 & $\begin{array}{l}4,34 \\
(0,23)^{A B a}\end{array}$ & $\begin{array}{c}4,60 \\
(0,43)\end{array}$ & $\begin{array}{c}4,82 \\
(0,36)\end{array}$ & $\begin{array}{c}5,00 \\
(0,33)\end{array}$ \\
\hline \multirow{3}{*}{$\begin{array}{c}E S T \\
(8)\end{array}$} & 1 & $\begin{array}{l}13,51 \\
(0.67)^{\mathrm{Aa}}\end{array}$ & $\begin{array}{l}13,50 \\
(0,36)^{A a}\end{array}$ & $\begin{array}{l}13,51 \\
(0,71)^{\mathrm{Aa}}\end{array}$ & $\begin{array}{l}13,42 \\
(0,72)^{\mathrm{Aa}}\end{array}$ \\
\hline & 2 & $\begin{array}{l}13.55 \\
(0.55)^{\mathrm{Aa}}\end{array}$ & $\begin{array}{l}13,43 \\
(0,33)^{\mathrm{Aa}}\end{array}$ & $\begin{array}{l}13,44 \\
(0,48)\end{array}$ & $\begin{array}{l}13,84 \\
(0,73)^{A a}\end{array}$ \\
\hline & 3 & $\begin{array}{l}13,51 \\
(0,61)^{\mathrm{Aa}}\end{array}$ & $\begin{array}{l}13,54 \\
(0,25)^{\mathrm{Aa}}\end{array}$ & $\begin{array}{l}19,52 \text { Aa } \\
(0,51)^{-}\end{array}$ & $\begin{array}{l}13,81 \mathrm{Aa} \\
(0,62)^{-}\end{array}$ \\
\hline \multirow{3}{*}{$\begin{array}{c}E S D \\
(8)\end{array}$} & 1 & $\begin{array}{c}9,44 \\
(0.62)^{\mathrm{Aa}}\end{array}$ & $\begin{array}{c}9.38 \\
(0,38)^{\mathrm{Aa}}\end{array}$ & $\begin{array}{c}9,27 \\
(0,58)\end{array}$ & $\begin{array}{c}9,28 \\
(0,64)^{\mathrm{Aa}}\end{array}$ \\
\hline & 2 & $\begin{array}{c}9,09 \\
(0,33)^{\mathrm{Aa}}\end{array}$ & $\begin{array}{c}8,97 \\
(0,42)^{\mathrm{Ba}}\end{array}$ & $\begin{array}{c}8,84 \\
(0,32)^{\mathrm{Ba}}\end{array}$ & $\begin{array}{c}9,17 \\
(0,21)^{\mathrm{Aa}}\end{array}$ \\
\hline & 3 & $\begin{array}{c}9,17 \\
(0,59)\end{array}$ & $\begin{array}{c}8,94 \\
(0,38)^{\mathrm{Ba}}\end{array}$ & $\begin{array}{c}8,69 \\
(0,25)^{\mathrm{Ba}}\end{array}$ & $\begin{array}{c}8,81 \\
(0,55)^{\mathrm{Ba}}\end{array}$ \\
\hline \multirow{3}{*}{$\begin{array}{c}\text { ACIDEZ . } \\
\text { (OD) }\end{array}$} & $=1$ & $\begin{array}{c}16,4 \\
(0,42)^{\mathrm{Aa}}\end{array}$ & $\begin{array}{c}16,3 \\
(0,27)^{\mathrm{Aa}}\end{array}$ & $\begin{array}{c}16,8 \\
(0,44)^{\mathrm{Aa}}\end{array}$ & $\begin{array}{c}16,5 \\
(0,50)^{\mathrm{Aa}}\end{array}$ \\
\hline & 2 & $\begin{array}{l}16,5 \\
(0,35)\end{array}$ & ${ }_{(0,42)^{\mathrm{Aa}}}^{16,4}$ & $\begin{array}{c}16,6 \\
(0,65)^{\mathrm{Aa}}\end{array}$ & $\begin{array}{c}16,4 \\
(0,42)^{\mathrm{Aa}}\end{array}$ \\
\hline & 3 & $\begin{array}{c}16,6 \\
(0,65)^{\mathrm{Aa}}\end{array}$ & $\begin{array}{c}16.5 \\
(0,35)^{\mathrm{Aa}}\end{array}$ & $\begin{array}{c}16,6{ }^{\mathrm{Aa}} \\
(0,65)\end{array}$ & $\begin{array}{c}16,5 \\
(0,36)^{\mathrm{Aa}}\end{array}$ \\
\hline \multirow{3}{*}{$\begin{array}{l}\text { DENSIDADE } \\
(9 / 1)\end{array}$} & 1 & $\begin{array}{l}1031,1{ }^{\mathrm{Aa}} \\
(0,17)^{-}\end{array}$ & $\begin{array}{l}1031,5 \\
(0,16)^{\mathrm{Aab}}\end{array}$ & $\begin{array}{l}1031,8 \\
(0,45)^{A b c}\end{array}$ & $\begin{array}{l}1032,1 \\
(0,16)^{A C}\end{array}$ \\
\hline & 2 & $\begin{array}{l}1031,3 \\
(0,35)^{\mathrm{Aa}}\end{array}$ & $\begin{array}{l}1031,7^{\text {Aab }} \\
(1,08)^{-1}\end{array}$ & $\begin{array}{l}1031,9 \\
(0,60)^{A b}\end{array}$ & $\begin{array}{l}1032,1{ }^{A b} \\
(0,31)^{-1}\end{array}$ \\
\hline & 3 & $\begin{array}{l}1011,3 \\
(0,21)^{\mathrm{Aa}}\end{array}$ & $\begin{array}{l}1031,6 \\
(0,34)^{\text {Aab }}\end{array}$ & $\begin{array}{l}1031,7^{A b} \\
(0,51)^{A b}\end{array}$ & $\begin{array}{l}1031,9 \\
(0,36)\end{array}$ \\
\hline
\end{tabular}

a/ Os valores entre Darêntesis correspondem ao desvio padrão da média.

b/ Letras maiúsculas diferentes indicam médias diferen tes nas amostragens.

c/ Letras minúsculas diferentes indicam médias diferen tes para os niveis de uréia. 
Os resultados obtidos neste experimento com a uréia substituindo parcialmente o farelo de soja e de algodão, como-fontes de nitrogênio, mostram que:

a) A uréia, como fonte alternativa de nitrogênio, nas condições e níveis utilizados neste trabalho, reduziu a pro dução leiteira das cabras. Entretanto, essa redução pode ser compensada economicamente pelo menor preço da uréia.

b) A presença de uréia no concentrado prejudicou a inges tão de alimentos, provavelmente em razão da diminuição da palatabilidade, mesmo no menor nível de substí tuição das fontes de NP .

c) A baixa aceitabilidade da ponta de cana de açúcar (terço final da planta), não recomenda a sua utilização como volumoso exclusivo para caprinos em lactação. 
d) A uréia pode ser utilizada na alimentação de caprinos até o nível de.substituição do equivalente a $10 \%$ da PD da dieta, sem afetar o desempenho ponderal dos an $\underline{i}$ mais.

e) A utilização de uréia na dieta de caprinos leitèìros pode levar a alterações nas características do leite, repre sentadas pelo aumento do teor de gordura e da densidade.

f) No estudo das características do leite, deve-se consí derar o efeito da época de amostragem somente para o teor de gordura e ESD. 


\section{LITERATURA CITADA}

AKINSOYINU, A.O.; A.U. MBA e F.O. OLUBAJO, 1977. Studies on milk yield and composition of the West African Dwart goat. Journal of Dairy Research, London, $\underline{44}(1): 57-60$.

ASSOCIATION OF OFFICIAL ANALYTICAL CHEMISTS (A.O.A.C.), 1965. Official methods of analysis. 10a. edição, Washington, DC. 957 p.

BHANDARI, D.S.; P.C. SANHNEY E.S.P. SING BEDI, 1973. Influence of sulphur and urea on growth and nutrient digestibility in goat kids. Indian Journal of Animal Science, New Delhi, $\underline{43}$ (10) : 936-939.

BHATTACHARYA, A.N., 1980. Research of goat nutrition and management in Mediterranean Middle East Adjacent Arab Countries. Journal of Dairy Science, Campaign, 63(10):1681-1700 . 
BLAIR, T.A., 1942. Climatology. New York, P'rentice-Hall, 484 p.

CAMPBELL, T.C.; R.G. LOSSLI; R.G. WARNER e I. TASAKI , 1963.

Utilization of biuret by ruminants. Journal of Animal Science, Albany, $22(1): 139-145$.

CHALUPA, W., 1968. Problems in feeding urea to ruminants. Journal of Animal Science, Albany, 27(1):207-219.

CHENOST, M. e P. BOUSQUET, 1974. Exploitation en vert du - Pangola pur la production de lait par les chevres. Annales de Zootechnie, Paris, 23(1):45-62.

CHICCO, C.F.; T.A. SHULTZ; E. SHULtZ; A.A. CARNEVALI e C.B. AMMERMAN, 1972. Molasses-urea for restricted forage feed steers in the tropics. Journal of Animal Science, Albany, $\underline{35}(4): 859-864$.

CONRAD, H.R. e J.W. HIBBS, 1968. Nitrogen utilization by ruminant. Apreciation of its nutritive value. Journal of Dairy Science, Campaign, $\underline{51}(2): 276-285$.

DEVENDRA, C., 1967. Studies on the nutrition of the indigenous. goat of Malaya. III. The requeriment for live weight gain. Malaysian Agricultural Journal, Kerala Lampur, $\underline{46}$ (1):98-103. 
DEVENDRA, C., $1972(a)$. The composition of milk of British Alpine and Anglo-nubian goats. World Review of Animal Production, Roma, 11(1):46-53.

DEVENDRA, C. ; $1972(\mathrm{~b})$. The composition of milk of British Alpine and Anglo-nubian goats imported into Trinidad. Journal of Dairy Research, London, $39(3): 381-385$.

DEVENDRA, C., 1980. Milk production in goats compared to buffalo and cattle in humid tropics. Journal of Dairy Science, Campaign, 63(10):1755-1767.

DEVENDRA, C., 1982. Goat: Dietary factors affecting milk secretion and composition. International Goat and Sheep Research, Scottsdale, $\underline{2}(1): 61-76$.

EMMANUEL, B. e M. EMADY, 1978. A comparative study of endogenous urea degradation in ruminants. Comparative Biochemistry and Physiology. Elms ford, 59 (2):215-217.

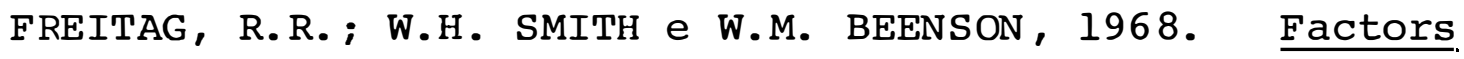
related to the utilization of urea v.s. protein-nitrogen supplemented diets by the ruminant. Joumal of Animal Science, Albany, 2그(2):478-483. 
FUJIHARA, T. e I. TASAKI, 1975. The efféct of abomasal infusion of urea on nitrogen retention in goats. Journal of Agricultural Science. London, 85(1): 185-188.

GIHAD, E.A., 1976. Intake, digestibility and nitrogen utilization of tropical natural grass hay by goats and sheep. Journal of Animal Science, Albany, $\underline{43}(4): 879-893$.

GOMES, F.P., 1976. Curso de Estatística Experimental. 6a. ed., Piracicaba, Livraria Nobel S.A., 430 p.

GONZALEZ, J.S.; J.J. ROBINSON; I. MCHATTIE e C. FRASER, 1982 . The effect in ewes of source and level of dietary protein on milk yield, and the relationship between the intestinal supply of non-amnonia nitrogen and the production of milk protein. Animal Production, Edinburgh, 34 (i): 31-40.

HAENLEIN, G.F.W., 1978. Dairy goat management. Journal of Dairy Science, Campaign, 63 (10):1707-1728.

HARRIS, B., 1980. Providing balanced nutrition for dairy goats. Journal of Dairy Goat, Scottsdale, 58(6):20-24.

HELMER, L.G. e E.E. BARTLEY, 1971. Progress in the utilization of urea as a protein replacer for ruminants. A review. Journal of Dairy Science, Campaign, 54(1):25-51. 
HOGAN, J.P. e R.H.' WESTON, 1969. The effects of antibiotics on ammonia accumulation and protein digestion in the rumen. Australian Journal of Agriculture Research, Melbourne, 20(2): $339-346$.

HUBER, J.T., 1975. Protein and non-protein nitrogen utilization in practical dairy rations. Journal of Animal Science, Albany, 41 ( 3 ) : 954-961.

HUBER, J.T. e R.A. SANDY, 1965. Response of dairy cows fed unlimited corn silage to three levels of urea and grain. Journal of Animal Science, Albany, 24(3):887 (Abstracts).

HUERTAS, E.; G. CEDEÑO; D. BULLes e R. RUBIO, 1972. Vários niveles de melaza de caña y urea suministrados en combination para production de leche. Revista do Instituto Colombiano Agropecuário. Bogotá, $\underline{7}(4)$ : 435-436.

ISLAM, M.M.; A. QUDDOOS e M.A. RAZZAQUE, 1977. Studies on. nitrogen balance and rate of utilization of urea by ruminants. Indian Veterinary Journal, Madras, $\underline{54}(5): 371-376$.

INSTITUT TECHNIQUE DE L'ELEVAGE OVIN ET CAPRIN (I.T.O.V.I.C.), 1982. Pratique de L'alimentation des Caprins-Conseils pour l'éleveur. Institut Technique de l'Elevage ovin et Caprin, Paris, 104 p. 
KERTZ, A.F. E J.P. EVERETT Jr., 1975. Utilization of urea by lactating cows. An industry viewpoint. Journal of Animal Science, Albany, $\underline{41}(3): 945-953$.

KONDOS, A.C., 1975. Studies on the adaptation of the rumen to the hydrolysis of biuret in cattle. Journal of Agricultural Science, Cambridge, $85(2): 351-357$.

KONDOS, A.C. е B. MUTCH, 1975. Biuret and urea in maintenance and production diets of cattle. Journal of Agricultural Science, Cambridge, 85 (2):359-368.

KRISHNA REDDY, T.V. e S.G. NAIR, 1972. A note on the utilization of dietary urea by goats. Indian Journal of Animal Science, New Delhi, $\underline{42}(3): 221-222$.

KURAR, C.K. e V.D. MUDGAL, 1981. Effect of plane of nutrition on the utilization of dietary energy in dry Beetal goats. Indian Journal of Animal Science, New Delhi, $\underline{\text { ll(3) }}$ :319-323.

LAMPILA, M., 1972. Practical nonprotein $-\mathrm{N}$-feeding to ruminants. World Review of Animal Production, Roma, $\underline{8}(3): 28-36$.

LE JAOUEN, J.C., 1978. Etude de la vocation laitiere de la chevre dans le cadre de systemes laitiers intensifs et de systemes mixtes lait-viande. Xx Congress International de Laiterie, ITOVIC, Paris, $13 \mathrm{p}$. 
MBÀ, A.U.; A.O. AKINSOYINU e F.O. OLUBAJO, 1974. studies on comparative utilization of urea and ground-nut-cake by West African Dwarf goats. Nigerian Society of Animal Production, Ibadan, $1(1): 209-213$.

MBA, A.U.; B.S. BOYO e V.A. OYENUGA, 1975. Studies on the milk composition of West African Dwarf, Red Sokoto and Saanen goats at differents stages of lactation. I. Total solids, butterfat, solids-not-fat, protein, lactose and energy of milk. Journal of Dairy Research, London, $\underline{42}(2): 217-226$.

MCDOWELL, L.R.; J.H. CONRAD; E.J. THOMAS E L.E. HARRIS， 1974. Tabelas de composição de alimentos da América Latina (Abreviada). University of Florida, Gainsville, 64 p.

MCLAREN, G.A.; G.C. ANDERSON; L.E: TSAI e K.M. BARTH , 1965. Level of readly fermentable carbohydrates and adaptation to all-urea supplemented rations. Journal of Nutrition, Bethesda, $87(1): 331-336$.

MELLO, A. e A. ROGICK, 1941. Estudo físico-químico e bacteriológico do leite de cabra em são Paulo. Boletim da Indústria Animal, São Paulo, $\underline{4}(2): 66-72$ :

MORAND-FERH, P. e D. SAUVANT, 1978. Nutrition and optimum performance of dairy goats. Livestock Production Science, Amsterdam, $\underline{5}(1): 203-213$. 
MORAND-FERH, P.: e D. SAUVANT, 1980. Composition and yield of goat milk as affected by nutritional manipulation. Journal of Dairy Science, Champaign, $\underline{63}(10): 1671-1680$.

MORAND-FERH, P.; D. SAUVANT e M. de SIMIANE, 1981a. L'alimentation de la chevre. World Review of Animal Production, Roma, 27(1):45-75.

MORAND-FEHR,P.;J.C. LE JAOUEN; Y. CHILLIARD e D. SAUVANT. 1981b. Les constituants du lait de chevre, synthese et facteurs de variation. In: ITOVIC. 6émes Journees de la recherche ovine et caprine. Tolouse, p. 234-270.

RAY, G.S. e M.D. PANDEY, 1980. Ingestive and eliminative behaviour of goat. Indian Veterinary Journal, Madras, $\underline{57(3):}$ $381-385$.

RINDSIG, R.B., 1977. Practical dairy goat feedings. Dairy Goat Journal, Scottsdale, $\underline{55}(6): 12-19$.

RUSH, I.G. e R. TOTUSEK, 1976. Suplemental value of feed grade biuret and urea-molasses for cows on dry winter grass. Journal of Animal Science, Albany, $\underline{42}(2): 497-505$.

RYS̄, R., 1967. Urea in rations for dairy cows. In: BRIGGS, M.H. Urea as a protein supplement. Oxford, Pergamon Press Ltd. , 466 p. 
SANDS, M. e R.E. MCDOWELL, 1978. The potential of the goat for milk production in the tropics. Ithaca, Cornell University, Department of Animal Science, 53 p. (Cornell International Agriculture Mimeograph) .

SAUER, F.D.; J.D. ERFLE; S. MAHADEVAN E J.R. LESSARD， 1979. Urea in corn silage as a supplemental nitrogen source for lactating cows. Canadian Journal of Animal Science, Ottawa, $\underline{49}(2): 403-410$.

SINGHAL, K.K., 1978. Comparative study of urea and biuret on feed utilization, growth and milk production in goats. National Dairy Research Institute Karnal (Hariana), 10 p. (Tese de Doutoramento).

SINGHAL, K.K. e V.D.MUDGAL, 1980a.Effect of urea and biuret feeding on water metabolism in growing and lactating goats. Indian Journal of Dairy Science, New Delhi, 33(4): 455-459.

SINGHAL, K.K. e V.D.MUDGAL, 1980b. Comparative study of urea and biuret feeding on nutrient utilization and milk production in goats. Indian Journal of Dairy Science, New Delhi, 33(2):161-164.

SINGHAL, K.K. e V.D. MUDGAL, 1981.Comparative study of urea and biuret on nutrient utilization and growth in goats. Indian Journal of Animal Science, New Delhi, 5l(1):55-60. 
SIRRY, I. e H.A. HASSAN, 1954. Composition of goat milk in Egypt. Indian Journal of Dairy Science, New Delhi, I(1):188$-193$.

SMITH, R.H., 1969. Nitrogen metabolism in the rumen. Journal of Dairy Research, London, $\underline{36}(3): 313-321$.

SMITH, G.S.; R.S. DUNBAR; G.A. MCLAREN; C. ANDERSON E J.A. WELCH, 1960. Measurement of the adaptation response to urea nitrogen utilization in the ruminants. Journal of Nutrition, Bethesda, $\underline{71}(1): 20-26$.

SREEMANNARAYANA, O. e B.B. MAHAPATRO, 1982. Growth rate and utilization of nutrients in Barbari kids feed with nitrogen from different sources. Indian Veterinary Journal, Madras, $\underline{59}(2): 147-152$.

STANGEL, H.J., 1967. History of the use of urea in ruminants feeds. In: BRIGGS, M.H. Urea as a protein supplement. Oxford, Pergamon Press Ltd., 466 p.

VAN HORN, H.H. e J.S. MUDD, 1971. Comparison of a liquid supplement of non protein nitrogen with urea and soybean meal for lactating cows. Journal of Dairy Science, Champaign, $\underline{54}(1): 58-64$. 
VAN HORN, H.H. e R.D. JACOBSON, 1971. Response of lactating cows to added. increments of dietary protein and nonprotein. nitrogen. Journal of Dairy Science, Champaign, 54(3):379-382.

VAN HORN; H.H. , 1980.Protein utilization and supplements for dairy goats. Dairy Goat Journal, Scottsdale, 58(3):48-50.

VAN SOEST, P.J., 1982. Nutritional ecology of the ruminant. Corvallis, O \& B Books inc., $373 \mathrm{p}$.

VIRTANEN, A.I., 1967. The production of milk on protein free rations. In: BRIGGS, M.H., Urea as a protein supplement. Oxford, Pergamon Press Ltd., $466 \mathrm{p}$. 